\title{
An assessment of hydrothermal alteration in the Santiaguito lava dome complex, Guatemala: implications for dome collapse hazards
}

\author{
Jessica L. Ball • Eliza S. Calder • Bernard E. Hubbard • \\ Marc L. Bernstein \\ Received: 20 April 2012 / Accepted: 5 December 2012 /Published online: 12 January 2013 \\ (C) The Author(s) 2013. This article is published with open access at Springerlink.com
}

\begin{abstract}
A combination of field mapping, geochemistry, and remote sensing methods has been employed to determine the extent of hydrothermal alteration and assess the potential for failure at the Santiaguito lava dome complex, Guatemala. The 90-year-old complex of four lava domes has only experienced relatively small and infrequent dome collapses in the past, which were associated with lava extrusion. However, existing evidence of an active hydrothermal system coupled with intense seasonal precipitation also presents ideal conditions for instability related to weakened clay-rich edifice rocks. Mapping of the Santiaguito dome complex identified structural features related to dome growth dynamics, potential areas of weakness related to erosion, and locations of fumarole fields. X-ray diffraction and backscattered electron images taken with scanning electron microscopy of dacite and ash samples collected from around fumaroles revealed only minor clay films, and little evidence of alteration. Mineral mapping using ASTER and Hyperion satellite images, however, suggest low-temperature $\left(<150^{\circ} \mathrm{C}\right)$ silicic alteration on erosional surfaces of the domes, but not the type of pervasive acid-sulfate alteration implicated in collapses of other altered edifices. To evaluate the possibility of internal alteration, we re-examined existing aqueous geochemical data from dome-fed hot springs. The data indicate significant water-rock interaction, but the $\mathrm{Na}-\mathrm{Mg}-\mathrm{K}$ geoindicator suggests only a short water residence time, and $\delta^{18} \mathrm{O} / \delta \mathrm{D}$ ratios show
\end{abstract}

Editorial responsibility: G. Giordano

J. L. Ball $(\bowtie) \cdot$ E. S. Calder $\cdot$ M. L. Bernstein

Department of Geology, University at Buffalo,

Buffalo, NY 14260-1350, USA

e-mail: jlball@buffalo.edu

B. E. Hubbard

Eastern Mineral Resources MS-954,

United States Geological Survey, 12201 Sunrise Valley Drive,

Reston, VA 20192, USA only minor shifts from the meteoric water line with little precipitation of secondary (alteration) minerals. Based on available data, hydrothermal alteration on the dome complex appears to be restricted to surficial deposits of hydrous silica, but the study has highlighted, importantly, that the 1902 eruption crater headwall of Santa María does show more advanced argillic alteration. We also cannot rule out the possibility of advanced alteration within the dome complex interior that is not accessible to the methods used here. It may therefore be prudent to employ geophysical methods to make further assessments in the future.

Keywords Hydrothermal alteration · Lava dome · Lava dome collapse $\cdot$ Remote sensing

\section{Introduction}

Hydrothermal systems in lava domes

A long-term result of the interaction of water (both meteoric and groundwater) with magma beneath silicic lava domes is the development and persistence of active hydrothermal systems. Within such systems, dome rocks can be altered to clay minerals, significantly weakening portions of an edifice, reducing slope stability and ultimately resulting in failure (Lopez and Williams 1993; Boudon et al. 1998; Reid et al. 2001; Crowley et al. 2003; Zimbelman et al. 2005; Opfergelt et al. 2006; John et al. 2008). At the Santiaguito lava dome complex of Santa María volcano in Guatemala, there is both an evident hydrothermal system and a regional climate characterized by intense bouts of precipitation during the wet season. This study involves an assessment of the degree of hydrothermal alteration using combined analytical and remote sensing approaches. In particular, the objectives are to characterize, to the extent possible, the alteration 
mineralogy in order to determine the maturity of the hydrothermal system, and to indicate areas of possible concern with respect to potential collapse of old and/or altered dome material.

The presence and assemblage of clay minerals in alteration products is particularly important. Clay-rich materials have the potential to absorb and channel groundwater, as well as increase the fluid pore pressure within an edifice. This in turn can reduce the factor of safety of the slope by promoting the formation of low-strength layers and hence increasing the risk of slope failure (Boudon et al. 1998). Increased pore water hosted in clays in edifice rocks can also create highly mobile cohesive debris flows, which can extend the effects of a sector collapse far beyond the potential runout of dry material (Scott et al. 2001; John et al. 2008).

Flank collapses can occur frequently and repeatedly in volcanic settings which host large, active hydrothermal systems, particularly in stratovolcanoes and silicic lava dome complexes (Vallance et al. 1995; Capra et al. 2002; Clavero et al. 2004). Two pertinent and recent examples are the 1998 debris flow at Casita in Nicaragua (Sheridan et al. 1999; Voight et al. 2002; Opfergelt et al. 2006) and the 1997 debris avalanche at Soufriere Hills, Montserrat (Sparks et al. 2002; Voight et al. 2002). At Casita, an 8-ka dacite lava dome complex, a 1.6 million $\mathrm{m}^{3}$ collapse generating a debris flow on 30 October 1998 was triggered by intense rainfall associated with Hurricane Mitch, and tragically resulted in more than 2,500 fatalities (Sheridan et al. 1999; Kerle 2002). It was found that intense hydrothermal activity had altered the rocks to easily erodible smectite clays (Opfergelt et al. 2006). For the 26 December 1997 debris avalanche at Soufriere Hills Volcano, Montserrat, hydrothermal alteration of the retaining crater wall was implicated as a major contributor to the destabilization and subsequent collapse and depressurization of the lava dome (Sparks et al. 2002; Voight et al. 2002). The resultant debris avalanche deposits contain abundant kaolinite and smectite group clays, alteration products typical of unsealed acid-sulfate hydrothermal systems. In both cases, these low-strength, low-permeability, fines-rich alteration materials were thought to have helped to concentrate water along and lubricate structural discontinuities, thereby reducing the shear strength of the rocks and ultimately leading to destabilization of the edifice (Voight et al. 2002; Opfergelt et al. 2006).

\section{Santiaguito lava dome complex at Santa María}

Santa María, an andesitic stratovolcano, was the site of a devastating and powerful Plinian eruption in October 1902. The eruption lasted for $36 \mathrm{~h}$, expelled more than $7.5 \mathrm{~km}^{3}$ of material, and left a $\sim 0.5-\mathrm{km}^{3}$ crater in the southern flank of the volcano (Rose 1972a; Williams and Self 1983). The resultant sector collapse scarp remains steep and highly unstable topography; it experiences frequent rockfalls and supplies debris to seasonal lahars and is itself a source of concern with respect to hazards. The focus of this study, however, is on the hydrothermal system associated with the historically and currently active Santiaguito lava domes which began extruding in the base of the crater in June 1922, 20 years after the eruption (Fig. 1a, b). In the 86 years since the dome-building eruptions began, a series of four lava domes have formed, totaling $\sim 1 \mathrm{~km}^{3}$ in volume: $\mathrm{El}$ Brujo, El Monje, La Mitad, and El Caliente (Fig. 1b) (Harris
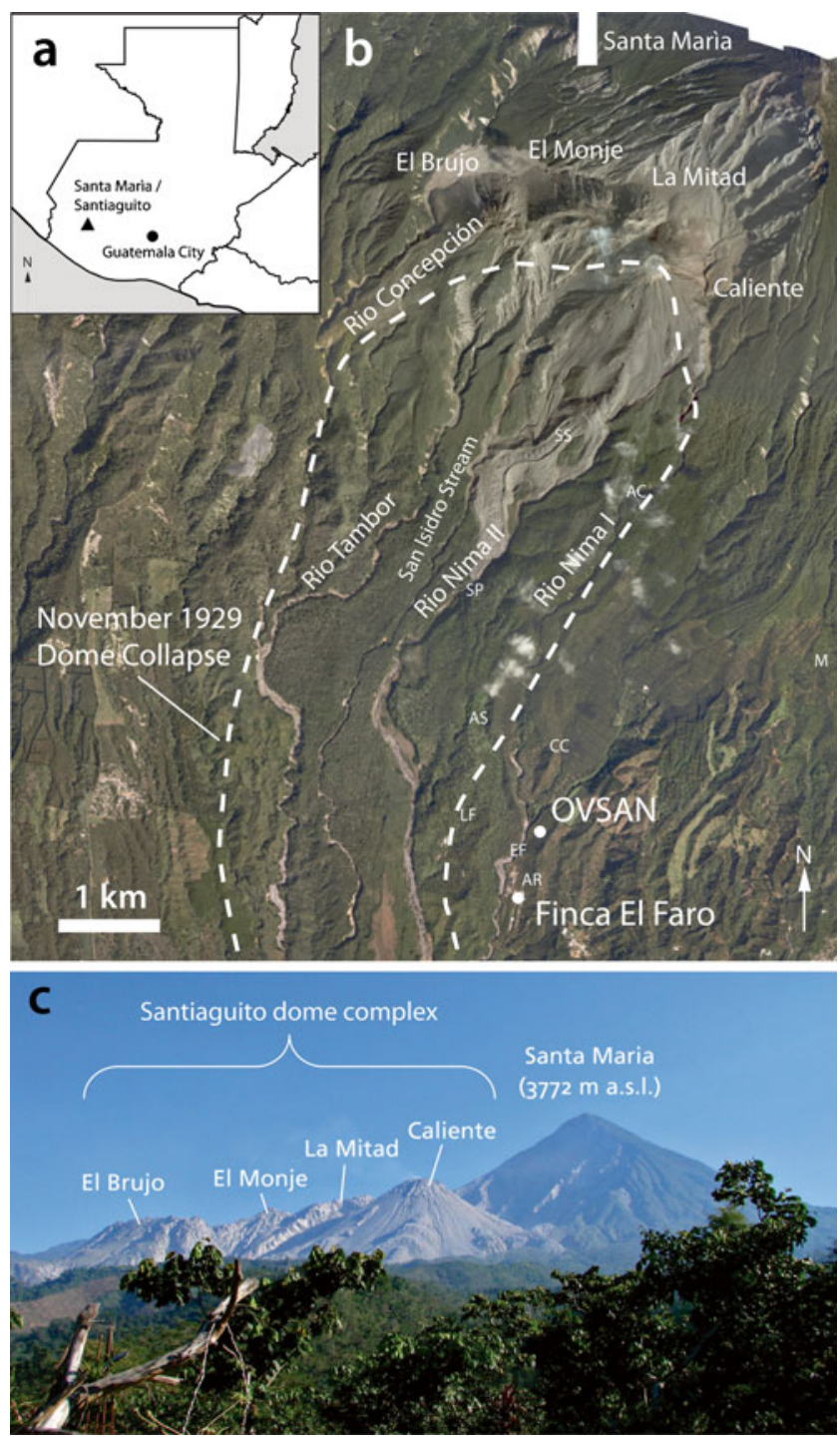

Fig. 1 a Location of Santa María/Santiaguito in Guatemala. b Aerial orthophoto of Santa María and the Santiaguito dome complex, with dome and river names. The Santiaguito Volcano Observatory (OVSAN) and headquarters of the Finca El Faro are located south of the domes. The extent of the 1929 dome collapse pyroclastic density current, the most extensive dome collapse generated at Santiaguito to date, continued approximately $4 \mathrm{~km}$ south of the limit of the image. The location of waters sampled by Walker et al. (2006) are indicated by letters ( $M$ meteoric water, $A C$ Agua Cascada, $A S$ Agua Sabina, $A R$ Armadillo, $C C$ Chichicaste, EF Finca El Faro, $L F$ Finca La Florida, $S P$ Santiaguito Spring, SS Santiaguito Stream. c The Santiaguito lava dome complex as viewed from OVSAN on the Finca El Faro 
et al. 2003). Dome growth has migrated from east to west, and has included associated Vulcanian explosions, effusion of a number of 1-4 km-long blocky lava flows, and lahars (Rose 1972b; Rose 1973a, b; Rose 1987a; Anderson et al. 1995; Harris et al. 2003). Unlike activity at some other lava dome eruptions (e.g., Sato et al. 1992; Cole et al. 1998; Calder et al. 2002), only relatively small and infrequent dome collapses have occurred at Santiaguito (Sapper and Termer 1930; Rose 1973a). The most extensive one (Fig. 1b), for which there are records, occurred on 2 November 1929, was approximately $\leq 3$ million $\mathrm{m}^{3}$, and was likely associated with the locus of active extrusion. Current activity at Santiaguito is focused at the Caliente vent (Fig. 1b), where slow lava extrusion and regular Vulcanian explosions occur at the dome summit (Venzke et al. 2002-2012; Johnson et al. 2004, 2008; Sahetapy-Engel et al. 2008).

For this study, an understanding of dome structure is important. The summit structure and activity of the currently active Caliente dome is controlled by the slow upward movement of a stiffened plug of dacite in a central conduit leading to both extrusion of a lava flow as well as periodic ash-and-gas eruptions (Bluth and Rose 2004; Johnson et al. 2004; Sahetapy-Engel et al. 2004; Johnson et al. 2008; Sahetapy-Engel et al. Sahetapy-Engel and Harris 2008); the structure of the other lava domes has not been well studied. Sapper and Termer (1930a) made early observations of endogenous growth of the dome complex in the 1920s, but multiple dome units and lava flows have erupted since (Rose 1972b; Rose 1987b; Harris et al. 2003, 2004). A comprehensive geological map of the broader dome complex has been presented by Escobar Wolf et al. (2010), which has provided a foundation for some of our work in determining more detailed dome structure ("Geomorphological mapping of the Santiaguito dome complex" section).

Intense bouts of precipitation have already been implicated as a triggering mechanism for collapses at lava dome eruptions even in the absence of hydrothermal alteration (Matthews et al. 2002; Elsworth et al. 2004; Simmons et al. 2004; Barclay et al. 2006; Matthews et al. 2009). Southwestern Guatemala hosts an extremely wet climate, with rainfall at the summit of Santa María $(3,772 \mathrm{~m})$ totaling more than $1,700 \mathrm{~mm}$ per year (Walker et al. 2006); precipitation rates at the dome complex have been estimated to be as much as 3,000-4,000 mm per year (Lopez 2004). The 1902 eruption crater of Santa María also drains precipitation directly onto alluvial plains at the foot of the Santiaguito domes (Fig. 2), which partially runs off in outlet channels to the east and west of the domes, but some of which evidently infiltrates into the base of the domes. The five principle drainage channels below Santiaguito (Fig. 1a-the Conception, Tambor, Nima I and II River valleys, and San Isidro Stream valley) likely receive a significant amount of recharge from the dome complex and crater area (Walker et al. 2006). Given their orientations, if a collapse occurred, the same drainages would direct collapse material or resulting debris flows into populated areas.

The Santa María-Santiaguito system has shown evidence of hydrothermal activity throughout its development. The crater of Santa María produced geysers and steam plumes, and hosted a crater lake for some months following the 1902 eruption (Winterton 1903; Sapper 1904). Once the domes extruded, Stoiber and Rose $(1969,1974)$ observed both high-temperature $\left(>150{ }^{\circ} \mathrm{C}\right)$ and low-temperature $\left(<150{ }^{\circ} \mathrm{C}\right)$ fumarole fields. They noted that low-temperature fumaroles were common on blocky talus slopes and that temperatures in the cooler fumaroles were sensitive to seasonal and even daily precipitation, decreasing by as much as $50{ }^{\circ} \mathrm{C}$ following bouts of rainfall. They also inferred that most of the gas emanating from the coolest fumaroles was from water of a meteoric origin as the ion contents of the fumarolic gases were consistently proportional to the concentrations found in dome lavas.

\section{Geomorphological mapping of the Santiaguito dome complex}

An understanding of the geomorphology and internal structural features of lava domes is important for hazard assessment as these features potentially provide planes of weakness which could facilitate collapse. Erosional scarps can expose the interiors of lava flows and lobes which can lead to undermining; ground fractures, vents, and shear lobe boundaries provide surfaces along which slip/slumping can occur. Drainage channels provide pathways to funnel debris flows and/or pyroclastic density currents resulting from those collapses.

Mapping on the Santiaguito dome complex was carried out through field work in February 2010, and based on highresolution aerial orthophotos taken in 2006 by the Instituto Geografico Nacional (IGN) of Guatemala, as well as DEMs generated from aerial photography in 2001 (JICA et al. 2003). Features such as the outline of the main lava flows and major alignments were adapted (in consultation with the authors) from Escobar Wolf et al. (2010). Our focus, however, was on mapping small-scale features such as individual shear lobes, extrusion directions and spines on the dome summits, as well as structures such as crater rims, vents, collapse scars, fumarole fields, and playas (small flatbottomed drainage basins with intermittent standing water; Fig. 3). The locations of erosional scarps and drainage channels were derived directly from the aerial photos.

Discrete extrusive vents, Fig. 3-marked in red, are visible on the summits of the El Brujo and Caliente domes, whereas areas where extrusion clearly occurred along linear zones are present near the summit of El Brujo and on the 

Santiaguito domes, taken from the NE to the SW of each dome (the left side of the profile is closer to Santa María, while the right is downslope of the volcano). Profile locations are indicated on the inset. Elevation is offset for clarity, but vertical/ horizontal scale is $1: 1$
Fig. 2 Profiles of the

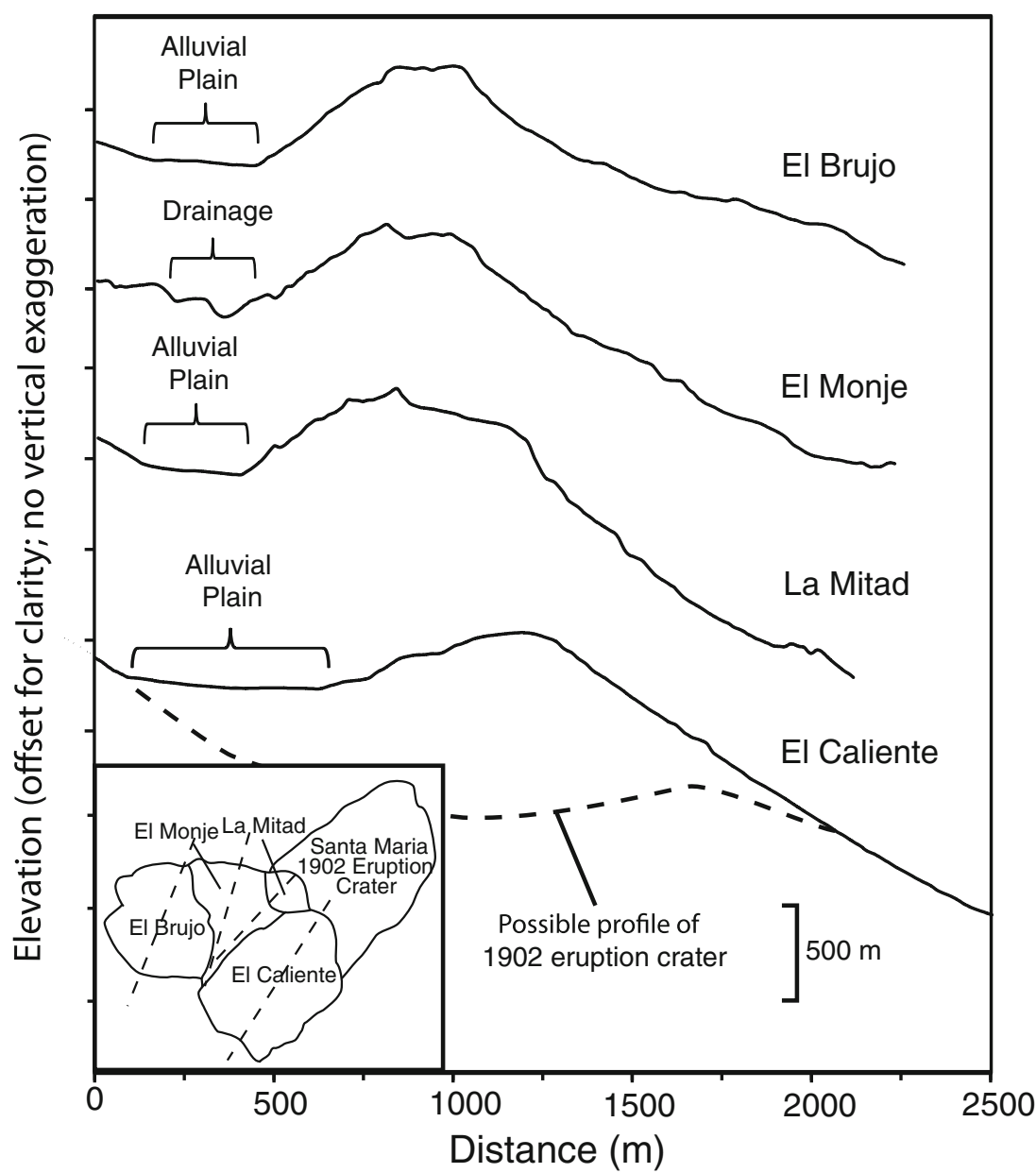

long axis of El Monje (Fig. 3). A number of arcuate ridges are located on all of the domes, the largest of which are associated with vents on the summits of El Brujo and Caliente; these are interpreted to be remnants of old crater rims. A smaller arcuate feature, interpreted to be a collapse scar, is located on the NW flank of El Brujo above a hummocky deposit which overlies an older lava flow (Fig. 3). Erosional scarps (outlined in green-Fig. 3) highlight areas where materials, such as talus and parts of lava flows, have been removed from the domes. These scarps are often associated, downstream, with established drainage channels (marked in blue-Fig. 3), although the northern side of El Brujo hosts numerous channels that do not have erosional scarps at their sources. Of particular note are the extensive erosional scarps on the SE flank of El Brujo and S flank of El Monje (Fig. 4), which expose layers of talus and the cores of several 10-30-m-thick lava flows.

Fumarole fields are common on all four domes (Fig. 3). There is a large field of low-temperature $\left(<150{ }^{\circ} \mathrm{C}\right)$ fumaroles in the saddle between El Brujo and El Monje, as well as isolated fumaroles around the spines on the crest of El Brujo and El Monje (Fig. 5). High-temperature fumaroles, observed with a high-resolution thermal imaging camera, are present only on the summit and high on the south flank of Caliente.

\section{Alteration mineralogy}

\section{Background}

In volcanic settings, hydrothermal alteration occurs by percolating fluids from magmatic degassing, convection and heating of meteoric groundwater, meteoric precipitation, or some combination of all three (John et al. 2008). The circulation of either low-temperature $\left(<150{ }^{\circ} \mathrm{C}\right)$ water and/or hotter acidic magmatic gases can promote the alteration of volcanic minerals and glass to clays. In particular, feldspars and volcanic glass, which are abundant in both mafic and felsic volcanic rocks, are especially prone to alteration (Wohletz and Heiken 1992; Velde 1995).

The specific alteration mineral assemblages in volcanic systems (Table 1) are useful indicators of fluid temperature and $\mathrm{pH}$ conditions (Utada 1980; Wohletz and Heiken 1992; Velde 1995; Thompson and Thompson 1996; Barnes 1997; Pirajno 2009). Acidic alteration (intermediate and advanced argillic) from the interaction of magmatic gases, particularly $\mathrm{SO}_{2}$ and $\mathrm{H}_{2} \mathrm{~S}$, with groundwater commonly produces kaolinite and smectite group clays, mainly by replacement of K-feldspar and glass. Higher $\mathrm{pH}$ conditions (sericitic/phyllic and propylitic alteration) produce clays and micas such as illite and sericite, as 


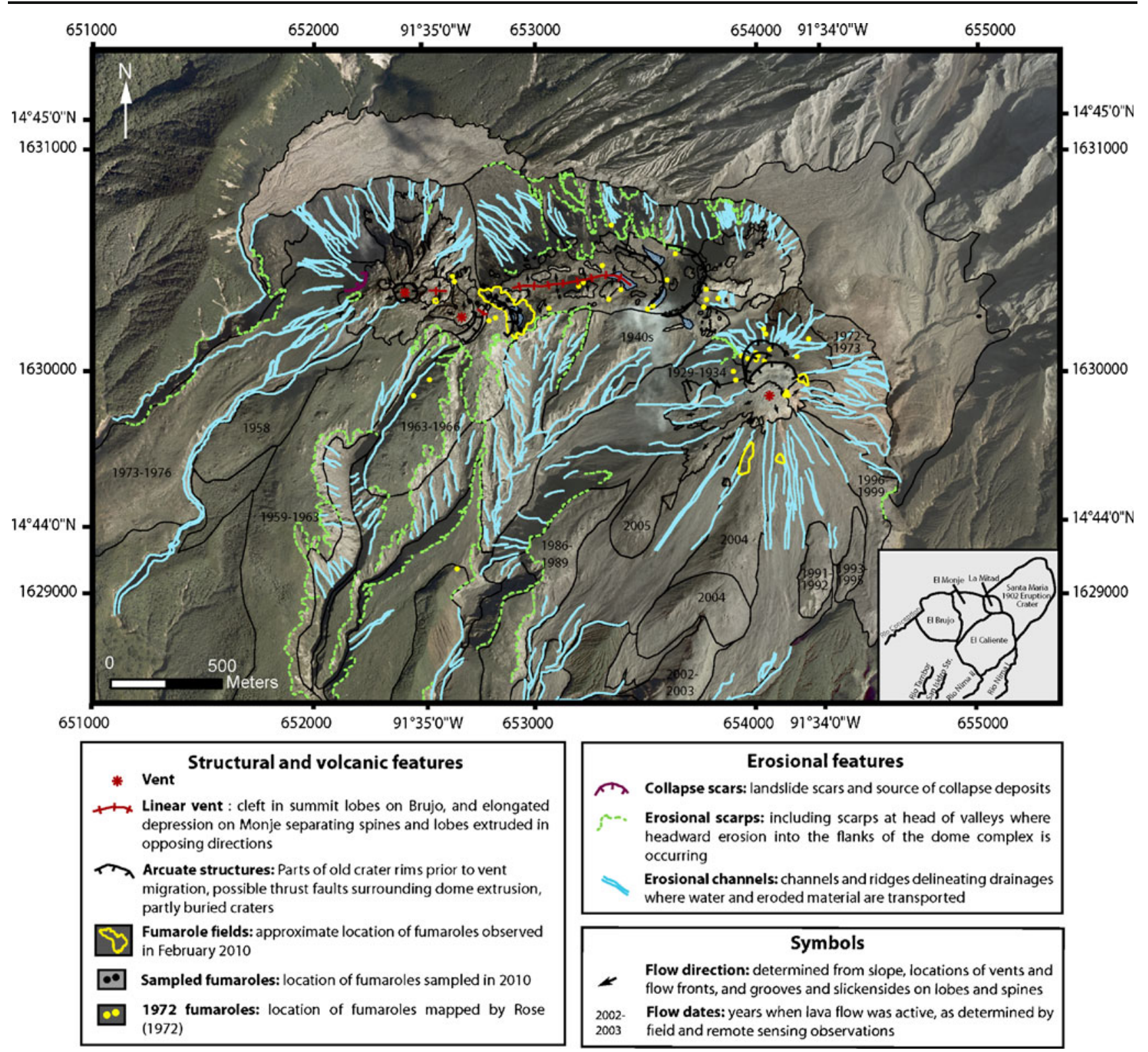

Fig. 3 Geomorphology of the Santiaguito lava dome complex. This map is developed as a companion map to Escobar Wolf et al. (2010), with the specific objective of detailed structural mapping of features of the lava domes themselves. Major lava flow outlines were modified from the previous geologic map with permission of the authors. Dome

well as biotite, epidote, quartz, chlorite, and minor sericite. Silicic alteration (which produces sinters of hydrous amorphous silica, including opal and chalcedony) indicates the presence of rock dissolution without transformation of minerals into secondary alteration products (Fournier 1985).

The location of hydrothermal alteration zones is controlled by structural variations in the host rocks, such as fracture distribution, porosity, and permeability; crater and vent locations; and large-scale features such as collapse scars and contacts between old and new volcanic edifices. All of these influence fluid circulation, and thus location of alteration growth structures, as well as erosional features, were mapped from aerial $0.5 \mathrm{~m} /$ pixel resolution aerial orthophotos 1860 -II-14 and 1860 II-19 (acquired between November 2005 and April 2006 by the IGN), as well as by direct field mapping. Data published by Rose et al. (1970) were also used to map fumarole locations

which commonly occurs along cracks, voids, and grain boundaries, both on small and large spatial scales (Velde 1995). These factors are all particularly relevant to lava dome complexes, which contain complicated networks of fractured and fragmented material such as multiple layers of lava and talus, and rocks of varying porosity and permeability.

Sample analysis

For this study, samples of lava and unconsolidated ash were collected from the interior walls of fumaroles on two 
Fig. 4 Erosional surfaces of the Santiaguito domes. a View from OVSAN, approximately $5 \mathrm{~km}$ south of the domes. Eroded surfaces are delineated by dashed lines, and include deep "barrancas" on the southwestern slopes of the dome complex. b Looking south from the saddle between El Monje and La Mitad at the eroded edge of a lava flow levee
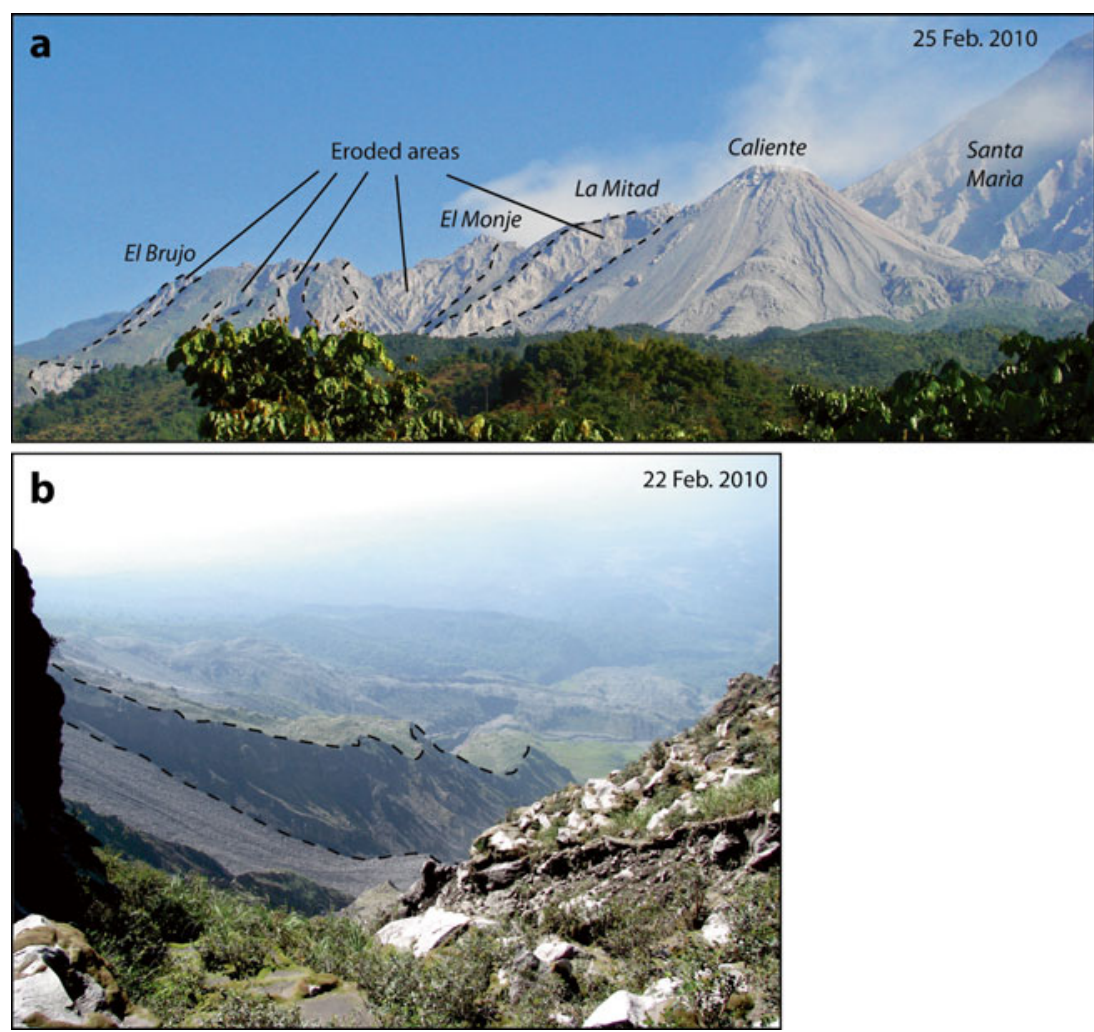

currently inactive domes (El Brujo and El Monje). The samples were collected in February 2010 from nine lowtemperature $\left(<150{ }^{\circ} \mathrm{C}\right)$ fumaroles; locations are noted on Fig. 2. Both X-ray diffraction (XRD) and visible to shortwave infrared (SWIR; 400-2,500 nm) laboratory spectral analyses (henceforward referred to as IR spectral analysis) were conducted on the sample suite. In particular, IR spectral reflectance measurements allow for direct comparison with, and ground truth validation of, remote sensing mapping results ("Remote sensing alteration mapping" section). For XRD, the samples were dissolved in deionized water and allowed to settle according to particle size separation methods described in Moore and Reynolds (1997). Airdried and oriented mounts on glass slides were made with a 2- $\mu \mathrm{m}$ clay suspension, also according to methods described by Moore and Reynolds (1997). Analyses were conducted on the Siemens D500 X-ray diffractometer, $\mathrm{CuK} \alpha$, graphite monochrometer at the University at Buffalo. XRD patterns (Fig. 6) were recorded for a scan range of $0-30^{\circ} 2 \theta$ with a step size of $0.02^{\circ} 2 \theta$ for each sample. Visible to infrared spectral reflectance measurements were made on the same powder and rock fragment samples using a Perkin-Elmer Lambda 900 laboratory spectrometer, with an internal artificial light source. Reflectance values were measured relative to "Spectralon," a high reflectivity white-colored plastic standard.

XRD results for samples 4, 7, and 9 (collected in the saddle between El Brujo and El Monje) are shown in
Fig. 6a, c, and, e, respectively, alongside corresponding IR spectral reflectance patterns for the same samples (Fig. 6b, $\mathrm{d}$, and $\mathrm{f}$ ). All three samples show peaks at $22^{\circ} 2 \theta$ and $28^{\circ} 2 \theta$ (Fig. 6a, c, and e) which are consistent with a secondary peak and the major peak, respectively, of a feldspar mineral (most likely plagioclase). Sample 7 (Fig. 6c) displays the strongest peak at $28^{\circ} 2 \theta$, suggesting it has the most abundant plagioclase feldspar of the three samples, while sample 9 (Fig. 6e) appears to contain less plagioclase feldspar relative to the vitric and amorphous phases that dominate the spectra. All three samples display curves with an apex in the $23-24^{\circ} 2 \theta$ range which indicate varying amounts of silica (opal-C or cristobalite). To distinguish between the two or determine precise amounts would require a more detailed analyses of the samples than could be undertaken for this study (Hillier and Lumsdon 2008; Hubbard, personal communication). However, the short-order crystalline structure of opal has long since been determined by studying its characteristic XRD patterns (Jones et al. 1964; Jones and Segnit 1971; Graetsch 1994). Amorphous opals such as precious opal, potch opal, and hyalite produce broad XRD peaks centered at approximately $23^{\circ} 2 \theta$ (for $\mathrm{CuKa}$ radiation). Peak broadening is indicative of decreasing amounts of short-order arrangement (e.g., sample 9-Fig. 6e). Better crystalline varieties (opal-C) give rise to either a sharper peak at $22^{\circ} 2 \theta$ (e.g., samples 4 and 7-Fig. 6a, c, respectively), a double peak between 20 and $24^{\circ} 2 \theta$ (opal-CT), or quartz peaks at $20.8^{\circ} 2 \theta$ and $26.67^{\circ} 2 \theta$ (chalcedony). Based 


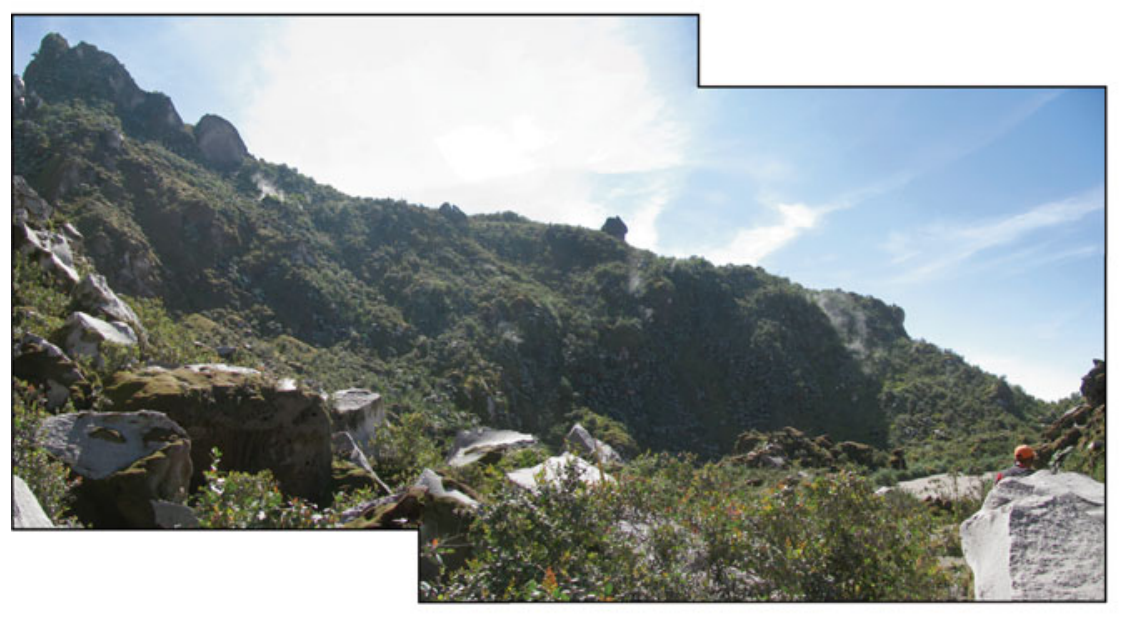

a

Fig. 5 Fumaroles in the saddle between El Brujo and El Monje domes. a Fumaroles on the El Monje side of the saddle expel mainly lowtemperature $\left(<200{ }^{\circ} \mathrm{C}\right)$ water vapor. b Fumaroles are common at the

on the relative intensities of the combined opal-C+plagioclase peak at $22^{\circ} 2 \theta$ (Fig. $6 \mathrm{a}$, c, and e), opal-C abundances appear to decrease from the highest in sample 4 (Fig. 6a), lower in sample 7 (Fig. 6c), and the lowest in sample 9 (Fig. 6e). This is also supported by the IR spectral reflectance patterns shown in Fig. 6b, d, and $\mathrm{f}$ which show decreasing yet broad hydrous silica absorption features between 2,120 and 2,360 nm (Graetsch et al. 1994) as they progress from sample 4 (Fig. 6b-strongest hydrous silica feature) through sample 7 (Fig. $6 \mathrm{~d}$ - moderate hydrous silica feature) to sample 9 (Fig. $6 \mathrm{f}$ - weakest hydrous silica absorption feature).

Additional samples (not shown) display XRD patterns devoid of sharp peaks, and are much shallower and broader in intensity than samples 4, 7, and 9 (Fig. 6). These other samples likely represent amorphous signatures from vitric

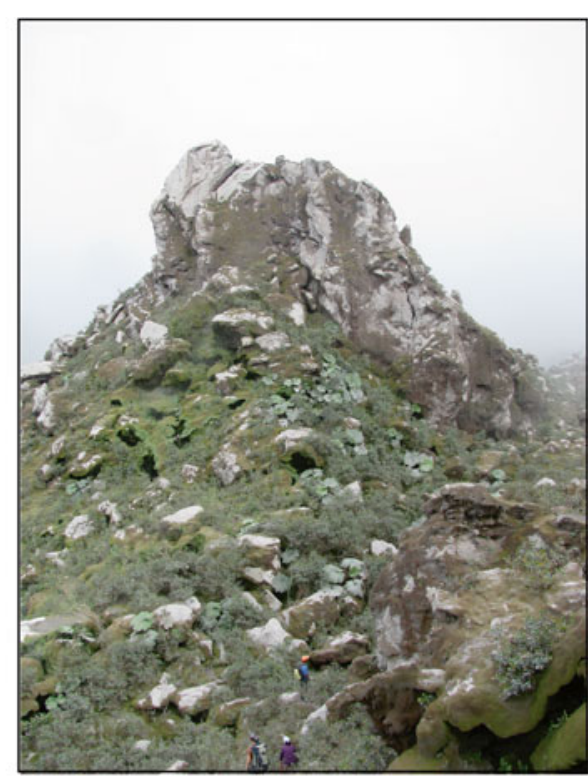

b base of spines and shear lobes, and have formed holes in the vegetated ash cover near a spine on El Monje

ash dominating the samples. In the analyses which did show sharp intensity peaks (Fig. 6a, c, and e), none correspond to recognized peaks for clay minerals, which would have been found in the $2.5-15^{\circ} 2 \theta$ range (Moore and Reynolds 1997). In these cases, it could be that small amounts of clay and/or sulfate alteration minerals are masked by the strong amorphous signature of volcanic glass. Because of this, secondary electron images were taken using a scanning electron microscope (SEM) in the unconsolidated ash and backscattered images (BSE) were collected from the thin sections, which could not be re-examined later by XRD. Additional qualitative measurements were conducted using energy dispersive X-Ray (EDS) analyses while the images were taken.

Samples of air-dried ash were placed on non-conducting, double-sided carbon-coated tape for secondary electron imaging. Double-polished thin sections were created from rock

Table 1 Summary of mineral assemblages associated with various types of alteration common in volcanic settings

\begin{tabular}{llll}
\hline Alteration type & Minerals & pH conditions & $\begin{array}{c}\text { Temperature } \\
\text { range }\left({ }^{\circ} \mathrm{C}\right)\end{array}$ \\
\hline Intermediate argillic & Smectite group clays, kaolinite, chlorite, minor sericite & Acidic & $100-300$ \\
Advanced argillic & Kaolinite, pyrophyllite, alunite, gypsum, opal & Very acidic & $100-300$ \\
Sericitic/phyllic & Sericite, white micas, epidote, chlorite, albite, k-feldspar, & Neutral to weakly & acidic \\
Propylitic & Quarte, minor kaolinite, illite, illite/smectite & Neutral & $200-300$ \\
Potassic & K-feldspar, biotite, pyrite, adularia & Acidic & 200-300 \\
Silicic & Quartz, chalcedony, opal & Neutral & $>500$ \\
\hline
\end{tabular}

Information summarized from Utada (1980), Wohletz and Heiken (1992), Velde (1995), Thompson and Thompson (1996), Barnes (1997), and Pirajno (2009) 
Fig. 6 Powder X-ray diffraction analyses (a, $\mathbf{c}$, and $\mathbf{e})$ and IR spectral analyses $(\mathbf{b}, \mathbf{d}$, and f) of samples of ash on glass slide mounts. All samples show a strong-to-weak curve indicating the presence of hydrous silica and plagioclase feldspar. Plagioclase is abbreviated to plag in mineral peak labels
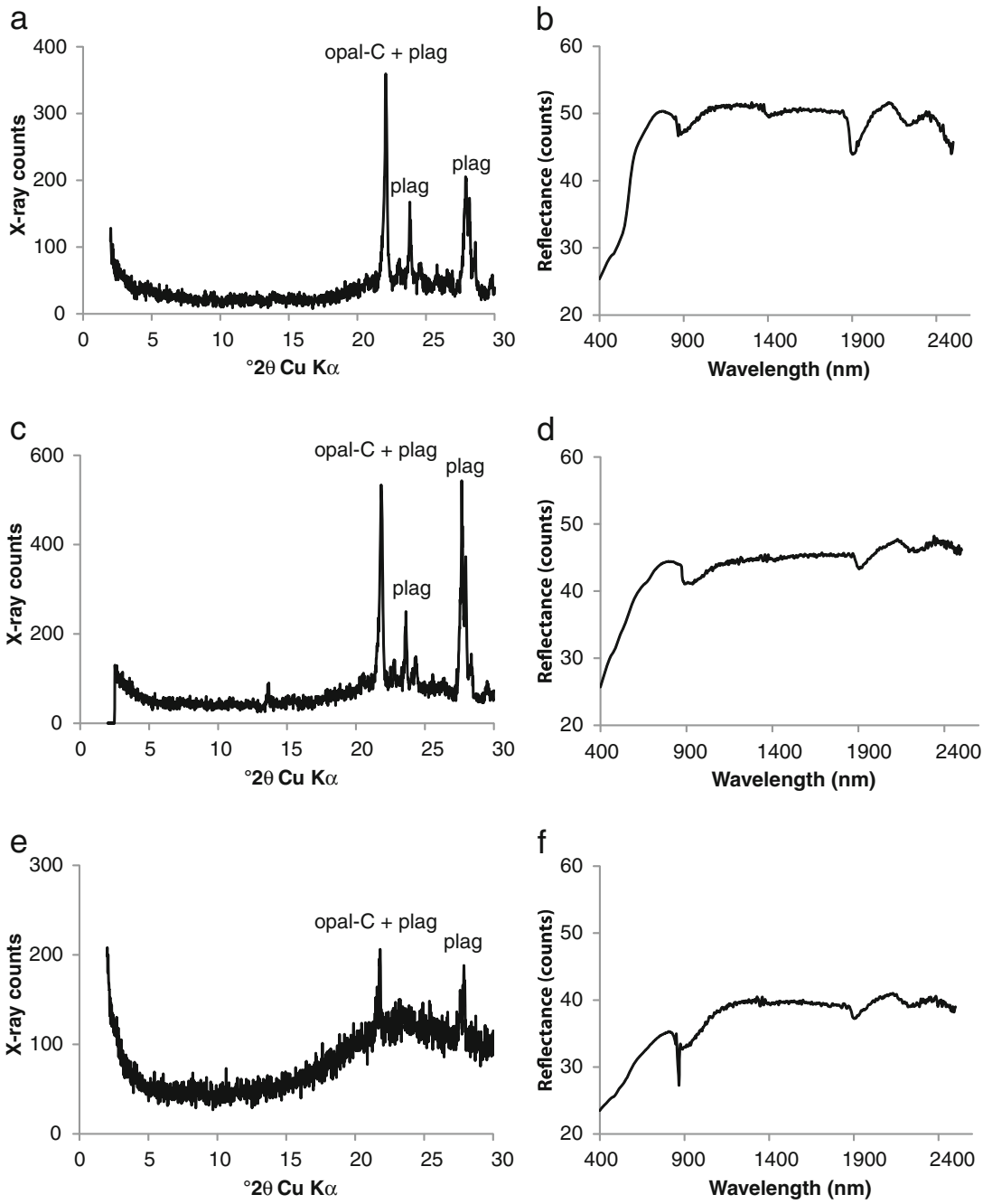

chips and were carbon-coated prior to analysis. Analyses were conducted on the Hitachi S-4000 Scanning Electron Microscope at the University at Buffalo South Campus Instrumentation Center. BSE images were collected at $20.0 \mathrm{kV}$, medium beam for thin sections, while secondary electron images were acquired of the ash samples. Qualitative chemical analyses were obtained using the EDS probe on the microscope.

Secondary electron images of ash (Fig. 7a, b) revealed blocky, equant grains in the 100-200- $\mu \mathrm{m}$ size range, with abundant adhering grains in the $0.5-10-\mu \mathrm{m}$ range. EDS measurements showed the larger grains to be mainly dacite glass or dacite groundmass, but some of the smaller grains evidenced chemistries consistent with montmorillonite clay. No well-developed crystalline forms were present, however, suggesting that the clay minerals were either amorphous or in the early stages of development (e.g., allophane and imogolite). Feldspars and void spaces in the thin sections contained abundant particles in the $<10-\mu \mathrm{m}$ size range (Fig. 8a, b), but while EDS sampling of these particles again returned clay and zeolite mineral chemistries, no image showed easily identifiable crystalline forms of the minerals.

\section{Remote sensing alteration mapping}

Background

Remote sensing using multi- and/or hyperspectral image data is particularly useful for mapping surface hydrothermal alteration in remote and inaccessible locations (Crowley and Zimbelman 1997) and therefore expands on the coverage obtained from the direct sampling. Clays and hydrous sulfate minerals (such as kaolinite and alunite) show distinct spectral features in the SWIR region, which spans 1,000 $2,500 \mathrm{~nm}$ in wavelength. Spectral features in these minerals are related to vibrations of structural hydroxyl groups and molecular water (Hunt and Ashley 1979). The Advanced Spaceborne Thermal Emission and Reflection Radiometer 

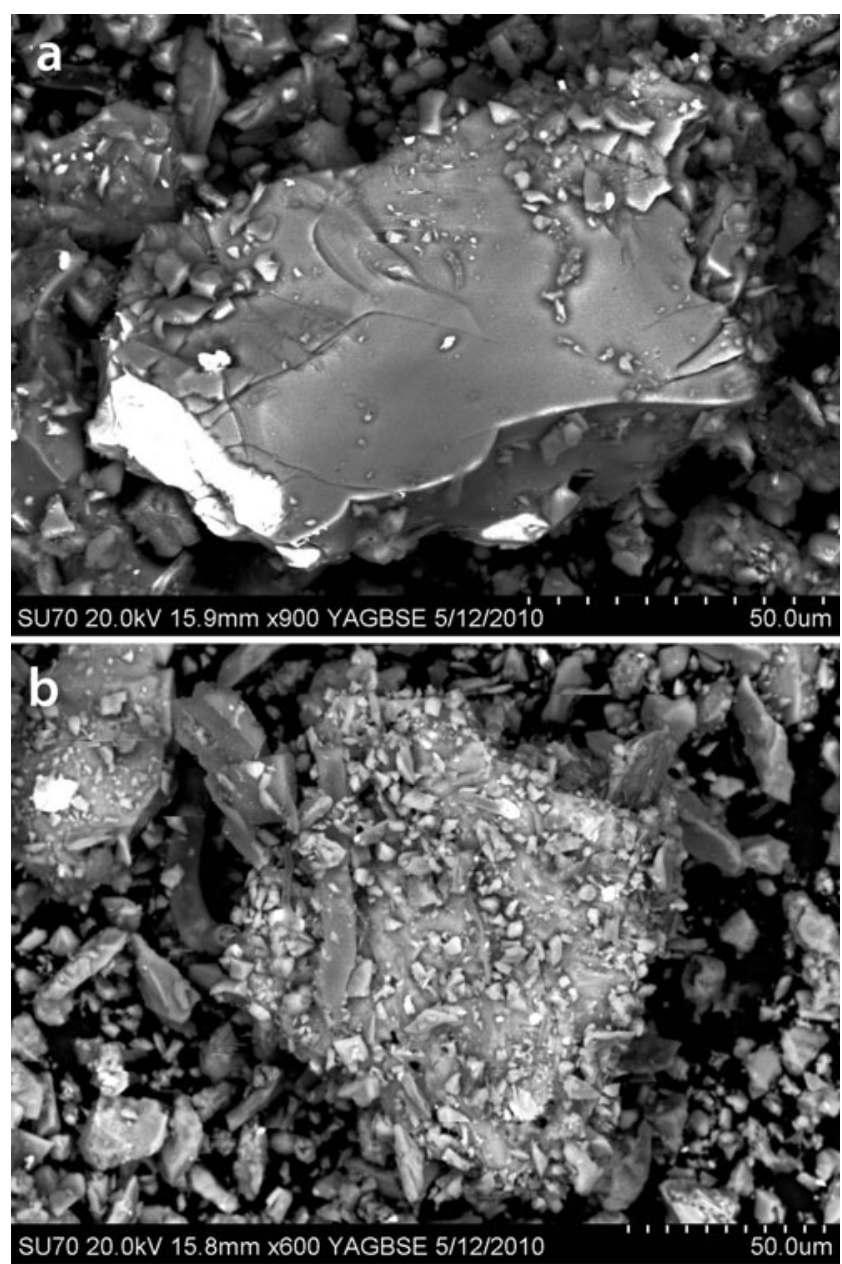

Fig. 7 a, b BSE images of ash from samples FMRL-07 and FMRL-08. EDS measurements indicated the presence of montmorillonite clay in the small $(\leq 10 \mu \mathrm{m})$ particles adhering to the larger ash particles

(ASTER) is a multispectral imaging instrument aboard NASA's Terra satellite, which also carries the Moderate Resolution Imaging Spectroradiometer (MODIS). ASTER operates in 14 bands, with 3 bands in the visible and nearinfrared (VNIR) region $(0.52-0.86 \mu \mathrm{m}), 6$ bands in the SWIR region $(1.6-2.43 \mu \mathrm{m})$, and 5 bands in the thermal infrared region $(8.125-11.65 \mu \mathrm{m})$, the latter of which are not used in this study. The MODIS sensor collects data on atmospheric moisture concurrently with ASTER scenes (Gao and Kaufman 1998) which are used to correct for atmospheric effects and for generating high-level ASTER image processing products (Mars and Rowan 2010; NASA 2004, 2011). Two images from the Hyperion spaceborne imaging spectrometer, on NASA's EO-1 satellite, are also used. Hyperion provides 242 spectral bands spanning $0.4-2.5 \mu \mathrm{m}$ in wavelength, with 172 channels in the critical SWIR region where diagnostic spectral absorption features related to clay, sulfate, and hydrous silica alteration minerals are most prominent (Hubbard et al. 2003).
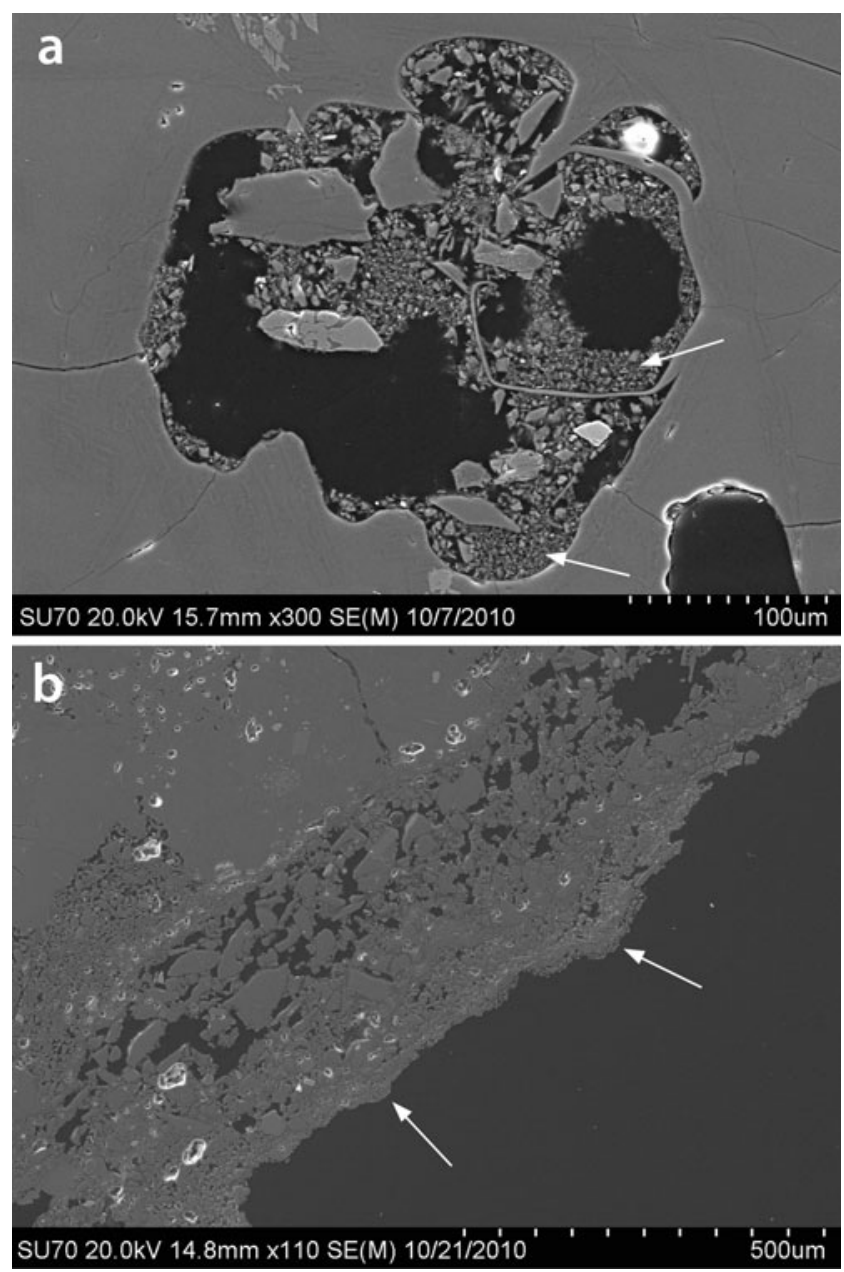

Fig. 8 a, b BSE images of samples FMRL-02B and FMRL-03 (thin sections). EDS measurements indicated the presence of montmorillonite clay and zeolites in the small particles in (a), and a predominantly silica rind on the edge of the sample in (b)

\section{Alteration mineral mapping}

ASTER Level 1B scenes were acquired on 22 January 2000, 8 December 2000, 4 January 2005, and 20 January 2005. The Hyperion scenes were acquired on 9 November 2001 and 21 February 2008. In all cases, image choice and analytical results were limited by atmospheric moisture, persistent cloud cover, the presence of thermal hot spots, and timing. The dome complex is often obscured by steam and ash plumes from activity at Caliente as well as atmospheric haze. Furthermore, instrument degradation in the ASTER SWIR sensor renders post-2007 SWIR data unusable (NASA 2008).

The VNIR bands of the ASTER scenes (15 m resolution) were resampled to SWIR $(30 \mathrm{~m})$ resolution in the ENVI image analysis program (ITT 2010), and the ACORN processing utility (ImSpec 2004) was used with Terra MODIS atmospheric moisture data to conduct atmospheric correction and calibration of "at sensor" radiance values to scaled reflectance from the surface. The Hyperion scenes (also at 
$30 \mathrm{~m}$ spatial resolution) were subset from 242 to 196 bands to eliminate repeating and unused bands. They were also calibrated to reflectance using ACORN, which corrects for atmospheric moisture on a pixel by pixel basis (e.g., Gao et al. 1993), as well as the column by column radiometric shifts in wavelength caused by the instrument's pushbroom engineering design (Folkman et al. 2001).

Our alteration mineral mapping procedures follow more detailed methods outlined in Hubbard et al. (2003), but are briefly described here as follows. Representative image spectra spanning the visible and near infrared (VNIR, 400-1,000 nm) and SWIR bands of both our ASTER and Hyperion scenes were determined. The resulting endmember spectra (Fig. 9a, b) were chosen using the Pixel Purity Index (PPI) method (Boardman et al. 1995) in order to locate the most homogeneous (or least mixed) targets. Prior to PPI analysis, vegetation and thermal hot spots $\left(<150{ }^{\circ} \mathrm{C}\right)$ were eliminated by masking, though dry vegetation lacking diagnostic chlorophyll spectral absorption features can still interfere with the identification of certain sericitic alteration minerals (van Ruitenbeek et al. 2006). The ASTER endmembers (Fig. 9a) and the Hyperion endmembers (Fig. 9b) were identified based on visual inspection and by comparison with reference spectra from the USGS mineral spectral library (Clark et al. 1993). A spectral matched-filter algorithm (Harsanyi and Chang 1994) and appropriate threshold values were then used to map the spatial distribution of pixels that best matched the characteristic shapes of the reference spectral endmembers (Fig. 9).
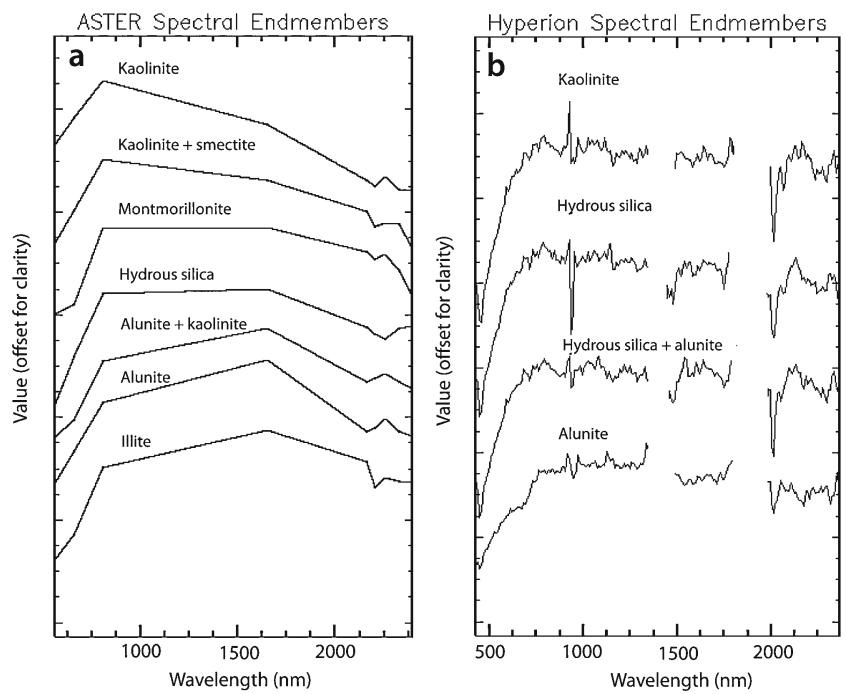

Fig. 9 a End member spectra for alteration minerals in ASTER 6-3-1 RGB images; profiles are offset for clarity. b End member spectra for minerals in Hyperion 2205-810-560 nm RGB images. Spectral profiles are offset for clarity; "bad bands" have been masked and appear as gaps in the profile. Note that these do not represent all of the spectra used for mapping, but are rather a subset of the best spectral patterns available for these minerals. Individual scenes were mapped using their own spectral end-members, chosen with the PPI method
The resulting mineral maps derived from the Hyperion and ASTER images reveal the presence of mainly hydrous silica alteration on exposed erosional surfaces of the domes (Fig. 10a, e, and f). Interestingly, ASTER (Fig. 10a, b, d) and Hyperion (Fig. 10c) maps also show mixtures of alunite, kaolinite, and hydrous silica (advanced argillic alteration) in the upper part of the 1902 eruption crater headwall scarp on the Santa María edifice. The ASTER image from 8 December 2000 (Fig. 10a) has the best atmospheric calibration conditions (i.e., lowest humidity), and also shows hydrous silica on the erosional scarp between the La Mitad and El Monje domes, as does the most current image (Hyperion from 22 January 2008, Fig. 10f). These hydrous silica minerals may be due to opal-A (hyalite), opal-C as suggested by our field and laboratory results, or perhaps even chalcedony, though the latter mineral and areas possibly containing it could not be accessed for sampling. Lesser amounts of argillic and phyllic mineral assemblages also appear to be present in scarps on the domes. However, hydrous silica minerals are more prevalent in the best-calibrated images (e.g., ASTER from 8 December 2000 - Fig. 10a and Hyperion from 22 January 2008 - Fig. 10f). Pixels that are mapped in some images, but not in others, are likely due to ash-cover from eruptions in between image dates, and/or poor calibration due to atmospheric water vapor, ash, and haze from fumaroles on the Caliente dome in the vicinity of circled hot spot areas (Fig. 10, all images). In addition, the general lack of mineral signatures on Caliente may also be due to the ash cover produced by frequent eruptions; this ash is more likely to persist on Caliente simply because it is often dispersed away from the other domes, and the ash that does fall on those domes is probably at least partially removed by seasonal rainfall.

\section{Aqueous geochemistry}

\section{Background}

Inferences about the origin and evolution of hydrothermal waters can be made by comparing their ${ }^{18} \mathrm{O} /{ }^{16} \mathrm{O}$ and deuterium/hydrogen $\left(\mathrm{D} / \mathrm{H}\right.$, or $\left.{ }^{2} \mathrm{H} /{ }^{1} \mathrm{H}\right)$ ratios with that of local meteoric (unequilabrated) water. Deviations from the Meteoric Water Line (MWL) of Taylor (1979), represented by the equation

$\delta \mathrm{D}=8 * \delta^{18} \mathrm{O}+10($ in per mil $)$

(where $\delta=\left(R_{\text {sample }} / R_{\text {standard }}-1\right) \times 1,000, R_{\text {sample }}$ is $\mathrm{D} / \mathrm{H}$ or ${ }^{18} \mathrm{O} /{ }^{16} \mathrm{O}$ in the sample), indicate interaction with host rocks or other fluids. Higher $\delta^{18} \mathrm{O}$ values indicate isotopic exchange with silicate and carbonate minerals in host rocks, which generally have $\delta^{18} \mathrm{O}$ values higher than +5.5 (Taylor 1979). The shift may be as small as 1 or $2 \%$ (e.g., in 

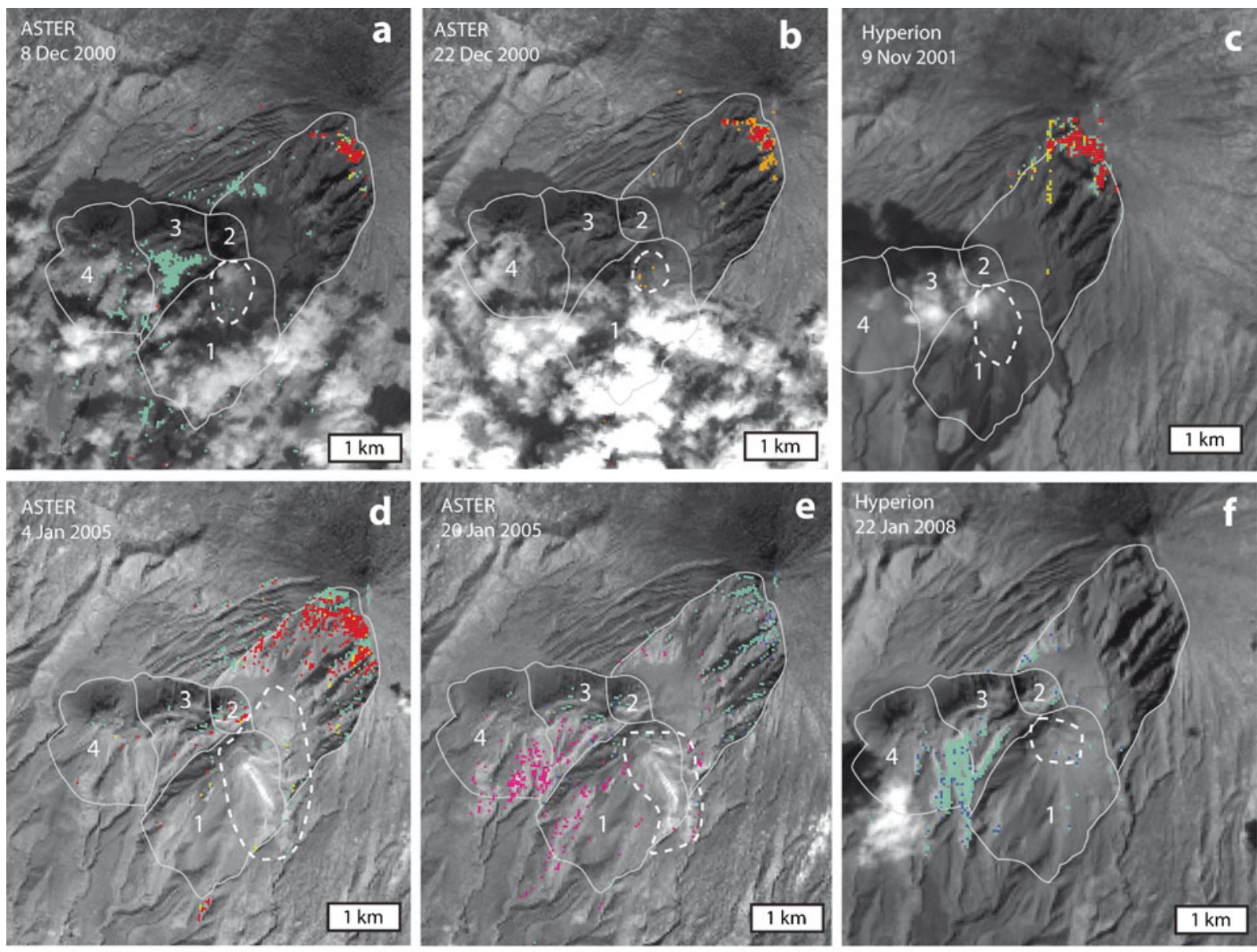

\begin{tabular}{|l|}
\hline$\square$ Kaolinite \\
$\square$ Kaolinite + Smectite \\
$\square$ Alunite + Kaolinite \\
$\square$ Hydrous silica \\
$\square$ Alunite \\
$\square$ Alunite + Hydrous silica \\
$\square$ Illite \\
$\square$ Montmorillonite \\
\hline
\end{tabular}

Fig. 10 a-f Results of end-member mineral mapping on ASTER (a, b, $\mathbf{d}, \mathbf{e})$ and Hyperion $(\mathbf{c}, \mathbf{f})$ images from multiple dates (noted on images). The 1902 eruption crater and dome boundaries are outlined; domes are numbered 1-4 (1 El Caliente, 2 La Mitad, 3 El Monje, 4 El Brujo). The analyses reveal concentrations of mainly argillic alteration assemblages

volcanic areas with a higher water/rock ratio), or as much as $15 \%$ (e.g., in very hot waters circulating through high- ${ }^{18} \mathrm{O}$ sediments). $\mathrm{D} / \mathrm{H}$ values are not greatly affected by this exchange because the rocks contain little initial hydrogen compared to the amounts of the water involved. A $\delta^{18} \mathrm{O}$ shift not only indicates that waters remain in the hydrothermal system long enough to exchange isotopes with the host rock but also increases the likelihood of alteration occurring as below the summit of Santa María, and mainly silicic (hydrous silica) assemblages on the eroded surfaces of the Santiaguito domes to the west of Caliente. Thermal hot spot features (fumaroles and lava flows) associated with the Caliente dome radiate brightly in the wavelength equivalent of ASTER band 6 and are marked with dashed outlines

the waters equilibrate. This may be further substantiated with $\mathrm{Na}-\mathrm{K}-\mathrm{Mg}$ geoindicators (Giggenbach 1988), which may be used to compare the relative cation contents of hydrothermal waters to known hydrothermal waters which have been classified as old (equilibrated with their surroundings) or young (not equilibrated with their surroundings).

A regional study of spring water geochemistry was undertaken by Templeton (1999) and later published by 
Walker et al. (2006). Their work detailed a sampling campaign conducted on numerous hot and cold springs in the vicinity of Santa María, as well as within the nearby Zunil geothermal field (located $7 \mathrm{~km}$ to the $\mathrm{NE}$ of the volcano). That study's goal was to understand regional provenances and characterizations of the hot springs through their aqueous geochemistry and stable isotope concentrations. Springs in the vicinity of Santa María and Santiaguito have a dominantly bicarbonate character and high $\mathrm{Na}^{+}$contents; Walker et al. (2006) interpreted this to be a result of interaction between spring water and rocks of the Santiaguito dome complex, which contain elevated amounts of sodium compared to other regional volcanic units (Rose 1987a; Walker et al. 2006). Recharge elevations calculated from stable ion ratios indicate that the springs are mainly supplied by surface runoff from Santa María, and stable isotope trends indicate that the water in the springs is mainly meteoric in origin (rather than magmatic). Although Santa María and Santiaguito are relatively close to the Zunil geothermal field, $\delta^{13} \mathrm{C}$ ratios suggest that the two hydrothermal systems are independent, and spring waters in the vicinity of Santiaguito and Santa María are affected solely by

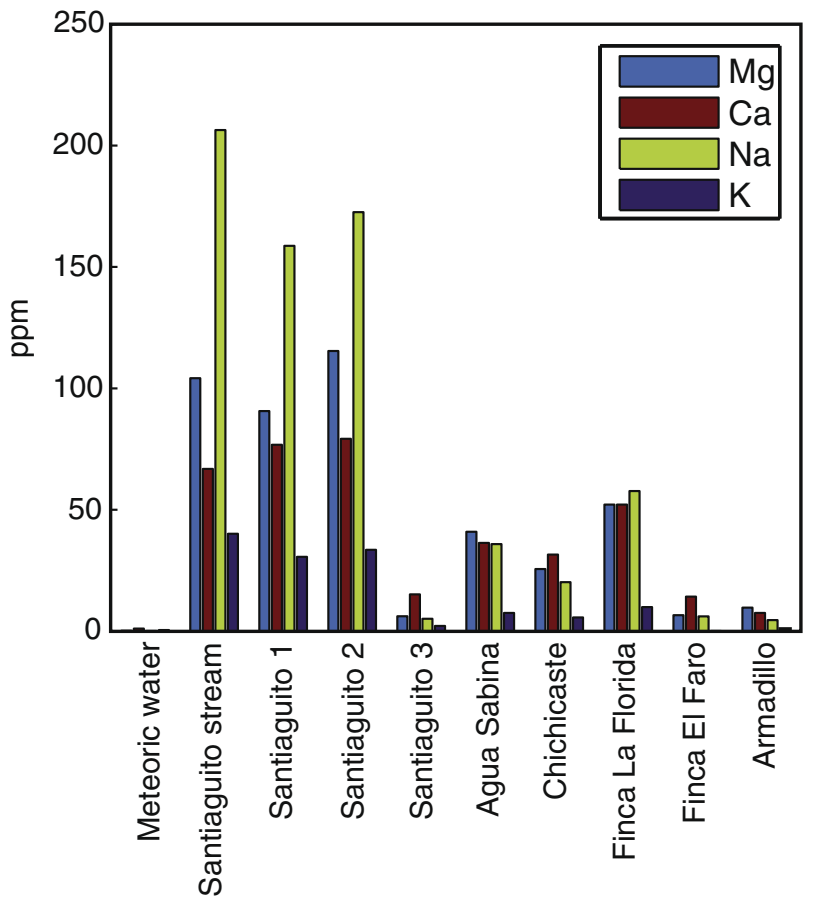

Fig. 11 Geochemical analyses of major cations in meteoric water, springs, and a surface stream near the Santiaguito dome complex. Locations (not including meteoric water) are ordered by increasing distance from the dome complex. In locations where multiple water samples were taken from the same spring, data are averaged; at Santiaguito springs 1, 2, and 3, samples were taken from separate springs and are thus treated as separate data sets. Data for figure from Walker et al. (2006)

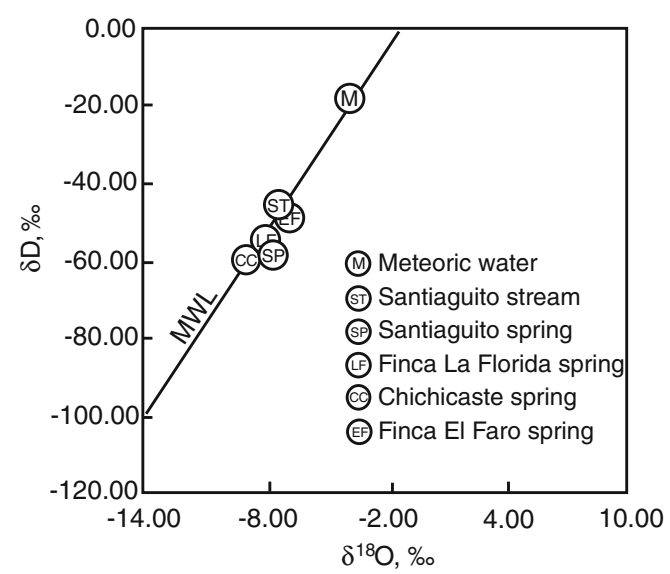

Fig. $12 \delta^{18} \mathrm{O} / \delta \mathrm{D}$ values for Santiaguito waters (figure modified from Walker et al. 2006). MWL is the local meteoric water line $(\delta \mathrm{D}=$ $8 \times \delta^{18} \mathrm{O}+10$ ). The analyses show no shift toward increased ${ }^{18} \mathrm{O}$, which is characteristic of hydrothermal systems containing alteration minerals (Taylor 1979)

shallow processes, such as those within the edifice (Walker et al. 2006).

Re-examination of local aqueous geochemistry

Here, we re-examine the geochemical data of Walker et al. (2006) from the perspective of alteration processes at Santiaguito, focusing on the data collected from nine springs in drainages below the dome complex (Fig. 1a). Cation contents in water were plotted in terms of total content and compared with meteoric and surface waters using the methods of Giggenbach for determining cation geoindicators (Giggenbach 1988). Hot spring waters around Santiaguito show an appreciable increase in major cations when compared to meteoric and surface runoff values (Fig. 11). In particular, $\mathrm{Na}, \mathrm{Ca}$, and $\mathrm{Mg}$ show the most significant increases; meteoric values for these cations are approximately zero, while surface runoff shows only a slight increase in ion content. There is a general trend of cation content decreasing with distance from the domes. Stable isotope ratios $\left(\delta^{18} \mathrm{O}\right.$ vs. $\left.\delta \mathrm{D}\right)$ of the waters around Santiaguito were compared with the MWL, $\delta \mathrm{D}=8 \times \delta^{18} \mathrm{O}+10$ ) to determine if there is an established geothermal system within the domes. For example, waters rich in $\mathrm{Cl}$ and acidic geothermal waters tend to show a significant shift toward higher $\delta^{18} \mathrm{O}$ values. This increase results from isotopic exchange with country rocks having initially high $\delta^{18} \mathrm{O}$ values (Hoefs 2004). A comparison of the stable isotope ratios for ${ }^{18} \mathrm{O} /{ }^{16} \mathrm{O}\left(\delta^{18} \mathrm{O}\right)$ and $\mathrm{D} / \mathrm{H}(\delta \mathrm{D})$ of these waters shows a slight shift away from the meteoric water line in those waters closest to the domes, but only $\sim 0.3-1.0 \%$ increase in $\delta^{18} \mathrm{O}$ (Fig. 12). When cation concentrations for the $\mathrm{Mg}-\mathrm{Na}-$ K system are plotted on Giggenbach's (1988) geoindicator diagram, they fall firmly in the immature waters field, as well as very near the meteoric water value (Fig. 13). 
Fig. 13 Ternary diagram of $\mathrm{Na} /$ $400, \mathrm{~K} / 10$, and $\sqrt{\mathrm{Mg}}$ after Giggenbach (1988).

Concentrations representing full water-rock equilibrium at temperatures from 20 to $300{ }^{\circ} \mathrm{C}$ are indicated by the "Full Equilibrium" line. Santiaguito waters plot as "immature." Figure modified from Walker et al. (2006)

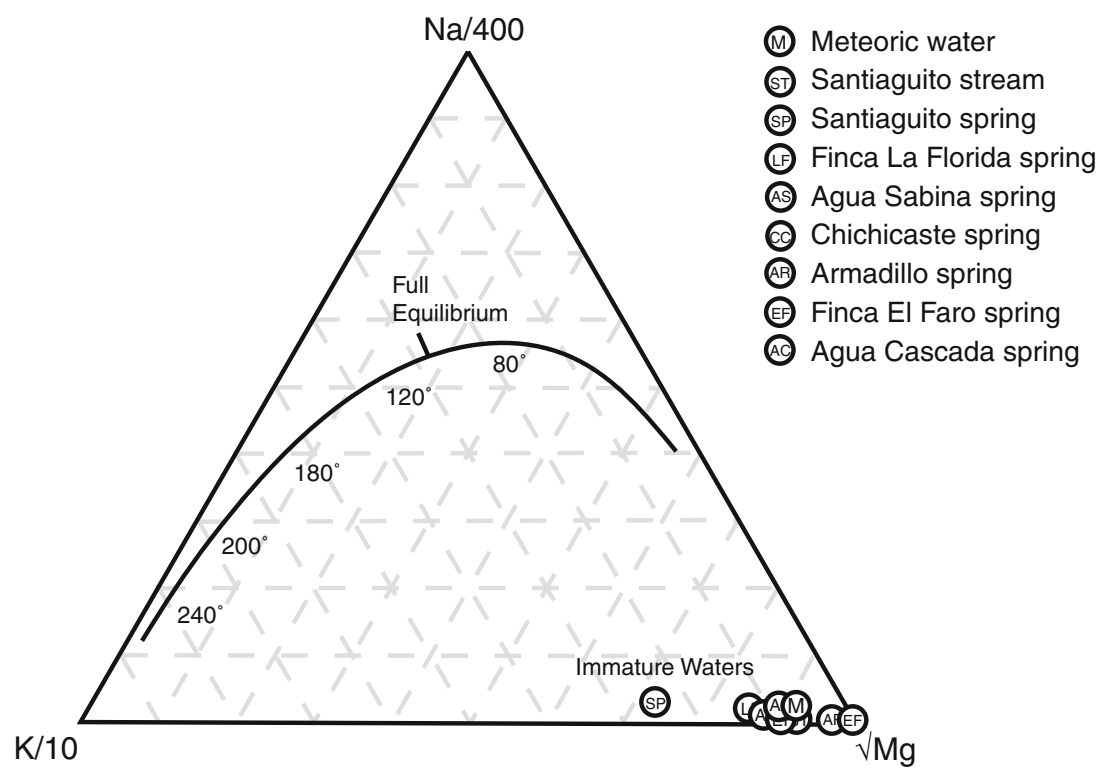

\section{Discussion}

Our remote sensing analyses are summarized together with fumarole and spring locations on an oblique DEM with a superimposed slope map (Fig. 14). Areas with slopes $>40^{\circ}$ are indicated, and zones rich in alteration often coincide with such slopes. This figure provides an overall framework for considering stability across the whole Santiaguito-Santa
María system; however, results from individual areas need to be considered.

The inactive domes (Brujo, Monje, and Mitad) are characterized by low-temperature fumaroles $\left(<150{ }^{\circ} \mathrm{C}\right)$ around their summits and show little surficial evidence of acidic alteration (as indicated in the alteration mineralogy and remote sensing results). The currently active Caliente dome clearly exhibits magmatic degassing (Holland et al. 2011),

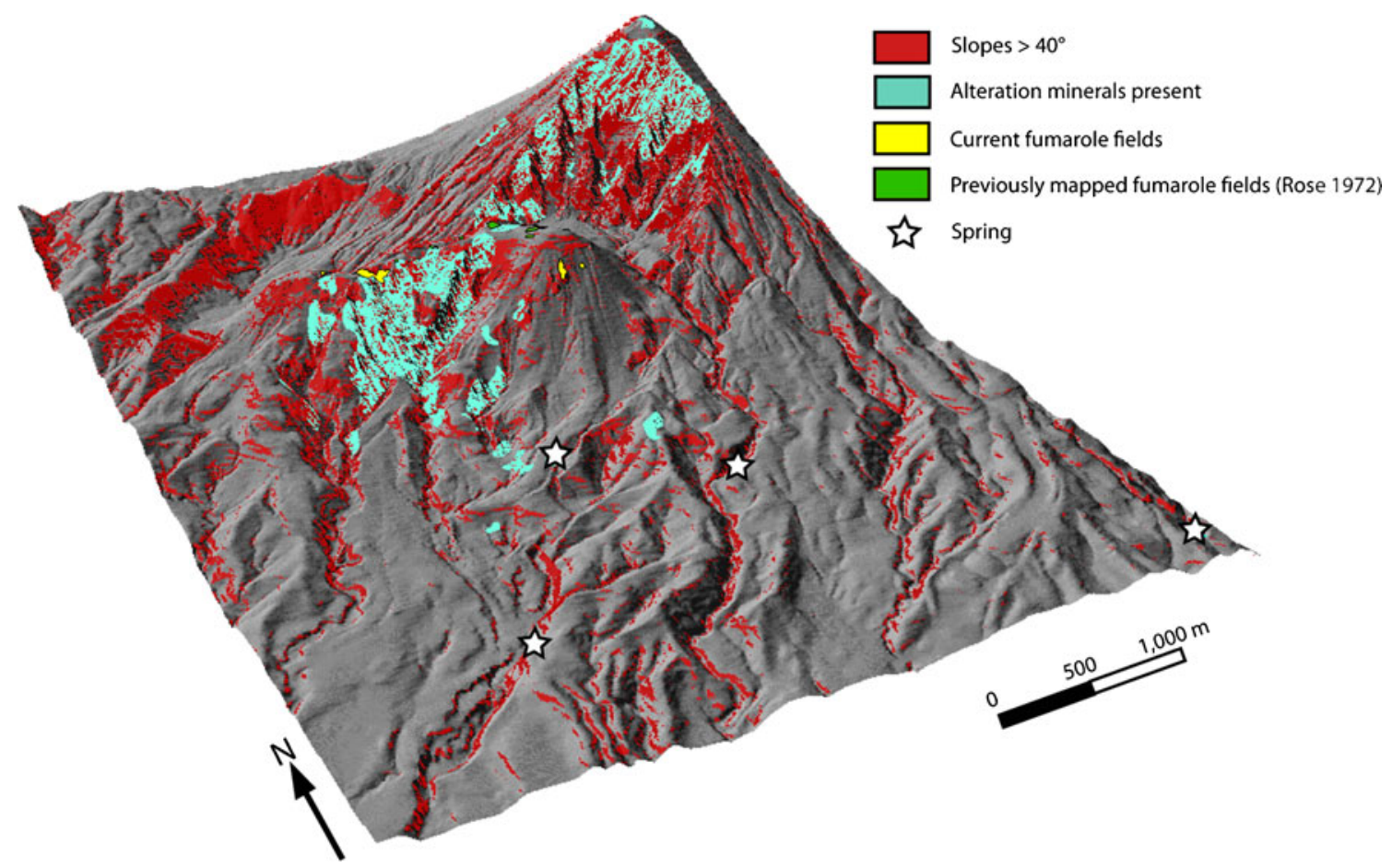

Fig. 14 3D oblique view of the Santiaguito complex and Santa María volcano. Colors represent areas of high slopes $\left(>40^{\circ}\right.$, in red), outlines of areas where alteration minerals are present (aqua), fumarole fields (yellow) and springs (stars). Zones of alteration were drawn from the combined geographical distribution of all alteration mineralogies determined from our remote sensing data (Fig. 10) 
but access for the purpose of direct sampling is too hazardous. Remote sensing results imply any surficial acidic alteration here is also minimal. Fumarolic activity on Caliente's summit is largely concentrated around the margins of active extrusion (Bluth et al. 2002, field observations) and on the northern part of the outer crater rim, but resurfacing by frequent deposition of fresh ash may also obscure bedrock signatures. The western domes have not erupted since the 1970s, and as such, the magmatic signature of their fumaroles might be expected to be significantly lower than those on Caliente. Meteoric water is likely an important component of these fumaroles; in this location, a shallow hydrothermal system dominated by meteoric water flowing through hot rock would lack the acid-sulfate components (from magmatic gases and fluids) that would enhance the effects of low-temperature alteration.

The dissolved ionic contents of springs draining the base of the Santiaguito dome hydrothermal system indicate significant water-rock interaction in the form of rock dissolution, but little isotopic exchange with the host rocks. Taylor (1979) indicated that while the $\delta^{18} \mathrm{O}$ shift caused by isotopic exchange (i.e., alteration mineral formation) was likely to be small, it would be on the order of at least $1-2 \%$. The $\delta^{18} \mathrm{O}$ shifts observed at Santiaguito are at most $0.5 \%$. We suggest that these slight shifts reflect residence times that are too short for the water to equilibrate with its host rocks, although dissolved ion contents indicate that some dissolution does occur. The $\mathrm{Na}-\mathrm{K}-\mathrm{Mg}$ geoindicator ternary diagram of Giggenbach (1988) corroborates this: The waters at Santiaguito fall in the immature field, indicating that they have not had sufficient time to fully or even partially equilibrate with the geothermal reservoir.

Meteoric water percolating through the ground to the water table would undergo heating and evaporation, which concentrates ions at ratios equal to that of meteoric water. This water flows a short distance through the domes within a few days to weeks (which would account for the lack of further water-rock interaction). Barnes (1997) states that equilibrium between fluids and silicate minerals is generally achieved on a time scale of weeks to months rather than days, which further supports the idea of a short water residence time involved here. The quantity of water moving through the domes, or the spring flux, was not measured, but may also be important. For example, Taylor (1979) suggests that the small isotopic shifts may be characteristic of volcanic areas with a high water-rock ratio. However, without knowing the spring flux and $\delta^{18} \mathrm{O}$ values of the dome lavas, it is impossible to verify whether a high water-rock ratio is inhibiting internal alteration.

Another factor that should be considered when discussing the apparent lack of alteration signatures in the springwater is the limited area that is drained by the hot springs sampled. The hot springs are clustered below the eastern part of the dome complex, mainly below Caliente. If their only inputs come from water draining through Caliente, then we can only say with certainty that Caliente is not likely to be experiencing internal hydrothermal alteration. The state of the interior of the other domes has yet to be determined; and because the inactive domes lack persistent drainage from springs, other geophysical methods would have to be employed to assess this.

The spectral mapping using ASTER multispectral and Hyperion hyperspectral satellite images does indicate the presence of hydrothermal alteration minerals on erosional surfaces of both the Santiaguito dome complex and the Santa María collapse scar headwall. Two different alteration mineral assemblages were mapped: (a) kaolinite and alunite mixtures in the summit area of the Santa María collapse scar related to advanced argillic alteration from acid-sulfate-rich fluids, and (b) steam-heated, fumarolic alteration dominated by hydrous-silica minerals such as opaline-silca (and perhaps chalcedony), which is consistent with low-temperature silicic alteration in the domes. These data support the geochemistry-based conclusion that the main hydrothermal fluid input to the domes is meteoric, and that minerals which are found in the XRD and SEM imaging of dome lava and ash samples are largely the result of dissolution of dome rock and precipitation of hydrous silica, with minimal to no clay mineral (e.g., montmorillonite) formation.

The prevalence of alunite and kaolinite at the summit of Santa María may indicate a once active magmatic-hydrothermal system dominated by acidic gases. We are not currently aware, however, of the existence of active fumaroles associated with the summit or eruption scar of Santa María. A self-potential and soil $\mathrm{CO}_{2}$ survey conducted by Bennati et al. (2011) of the area around Santa María (but not extending to the Santiaguito dome complex) was interpreted to indicate the potential presence of a hydrothermal system, related to a residual magmatic body from the 1902 eruption, extending radially about $800 \mathrm{~m}$ from the summit of Santa María. Additional kaolinite-mapped pixels within the Santa María scar and downslope of the domes may be due to small debris flows, alluvium, and colluvium originating from the kaolinite-rich source areas exposed along the headwall summit scarp of Santa María.

Wohletz and Heiken (1992) and Lynne et al. (2008) note that opal sinters may be formed when the temperatures in hydrothermal waters drop below $100{ }^{\circ} \mathrm{C}$, and hydrous silicate minerals can then precipitate out of solution. We observed hydrous silicate minerals on erosional scarps of the dome complex, which would be consistent with water dissolving silica from dome rock and then cooling as it percolates out to the surface. The precipitation of siliceous sinter, in sufficient quantities, may have implications for dome stability and/or dome permeability (Boudon et al. 1998; Komorowski et al. 1997; Komorowski et al. 2010). Based on our work, however, we cannot determine whether sinter at Santiaguito is sufficiently pervasive to have such effects. 
Although the original goals of this study were to map alteration on the Santiaguito dome complex, the remote sensing evidence of acidic alteration on the summit of Santa María and its implications should be discussed. The 1902 eruption scar is already known to be a site of active and continuous erosion, and even a cursory look at the morphology of the summit of Santa María shows very steep, and in some places vertical cliffs (Fig. 14). The remote sensing evidence for acidic alteration and clay minerals and the precipitous topography in this area leads us to conclude that rockfalls from the scarp, some of significant volume, are likely a more immediate risk than collapses from the domes themselves. The analytical data collected here did not extend to the Santa María scarp, so the remote sensing data that indicate the presence of advanced argillic alteration require ground truthing. Confirmation of the presence of extensive regions of alteration combined with oversteepened topography as well as environmental agitators such as intense precipitation and/or regional earthquakes would clearly indicate that collapses from the upper scarp region present significant risk. Monitoring of the conditions related to deformation and morphological evolution of this region should be implemented, including simple and regular checks for ground cracks. Future work might also include determining volumes of altered material on Santa María, which could then be used in forward models to predict the impact of a collapse of the summit scarp on downslope regions (Hubbard 2001; Crowley et al. 2003).

\section{Conclusions}

While the geochemical analyses conducted in this study provide evidence that the Santiaguito dome complex does not host pervasive hydrothermal alteration, there is some evidence in our remote sensing results for limited and perhaps localized presence of clay minerals on the dome surfaces. The lack of evidence for more pervasive alteration (i.e., advanced argillic alteration similar to that on Santa María) on the domes is somewhat curious, given the feldspathic lavas and wet, low-temperature conditions, which could favor clay mineral formation. This certainly does not, however, preclude the possibility that internal alteration is occurring that could contribute to the instability of the lava domes, nor does it rule out collapses triggered by other processes such as exogenous dome growth or endogenous injection of new magma, or regional seismic activity.

The spectral end-member mapping results were somewhat limited by cloud-cover, surface ash-cover, atmospheric humidity issues, gases from active fumaroles, and haze from both wildfires and the active Caliente dome. These conditions are common problems when using satellite imagery to map minerals at volcanoes in tropical and (or) developed areas. However, persistent observations of the same area (in this case, over an 8-year period) can still yield useful information about hydrothermally altered bedrock by catching rare, but ideal conditions needed for clear imagery and good exposures of altered rocks beneath ash, vegetation, or snow cover. In the case of Santiaguito, multiple images reveal reasonably consistent information about alteration mineral types and locations, which can be tested through on-theground sampling. Geochemical data from ash and lavas around the fumaroles confirm the presence of silicic sinter on the domes, while clay and sulfate minerals indicative of a higher degree of potential edifice-collapse hazard are mainly observed within the summit scarp of Santa María.

The aqueous geochemistry of springs around the base of the domes seems to indicate that while water-rock interaction (e.g., dissolution and precipitation of silica) is occurring, clay mineral formation is unlikely in the area of the dome complex that is drained by the hot springs sampled in Walker et al. (2006) and Templeton (1999). Clustering of the spring water geochemical data in the immature field suggests that the meteoric waters supplying these springs spend relatively little time within the domes. Also, with their nearneutral $\mathrm{pH}$ values, this deprives the dome hydrothermal systems of two important factors: acidity and long water residence time, either of which would contribute to more intense hydrothermal alteration.

The limited area drained by the springs sampled precludes us from saying conclusively that there is no hydrothermal alteration occurring within the domes. It may be possible that internal alteration is occurring, but not in areas that drain into the hot springs. In order to assess this, future geophysical surveys such as electrical resistivity/conductivity, self-potential, or magnetotellurics (Fuji-ta et al. 1999; Finn et al. 2001; Nicollin et al. 2006; Bedrosian et al. 2007; Finn et al. 2007; Komori et al. 2010; Lesparre et al. 2012) would be necessary. Finally, and of some concern, is that the results found here indicate that the precipitous cliffs near the headwall of the Santa María scarp are additionally compromised by the indication that argillic alteration is prevalent there. The region is prone to seismic hazards and precipitation rates which could both diminish stability and trigger collapses from the scarp headwall. We suggest that it would be useful to focus further work on assessing hazards related to such a collapse.

Acknowledgments This material is based upon work supported by the National Science Foundation under a Graduate Research Fellowship under grant \#1090871 and a Geological Society of America Graduate Student Research Grant awarded to J. L. Ball, as well as National Science Foundation Grant \#EAR0809543. The authors would also like to thank Rüdiger Escobar Wolf for sharing his expertise and providing feedback on our geomorphologic map, and Gustavo Chigna and Julio Cornejo (INSIVUMEH / Santiaguito Volcano Observatory, OVSAN) for their support and input in the field. Dr. Ross Giese 
(University at Buffalo) provided analytical support for the XRD analyses, and Peter Bush donated time on the UB South Campus Instrumentation Center SEM. Finally, the authors wish to thank P. Delmelle, JC Komorowski, J. Mars (USGS), and an anonymous reviewer for their comments and suggestions for improving the manuscript.

Open Access This article is distributed under the terms of the Creative Commons Attribution License which permits any use, distribution, and reproduction in any medium, provided the original author(s) and the source are credited.

\section{References}

Anderson SW, Fink JH, Rose WI (1995) Mount St Helens and Santiaguito lava domes: the effect of short-term eruption rate on surface texture and degassing processes. J Volcanol Geotherm Res 69(1-2):105-116

Barclay J, Johnstone J, Matthews A (2006) Meteorological monitoring of an active volcano: implications for eruption prediction. J Volcanol Geotherm Res 150(4):339-358. doi:10.1016/j.jvolgeores.2005.07.020

Barnes HL (1997) Geochemistry of hydrothermal ore deposits. Wiley, New York

Bedrosian P, Unsworth M, Johnston M (2007) Hydrothermal circulation at Mount St. Helens determined by self-potential measurements. J Volcanol Geotherm Res 160(1-2):137-146. doi:10.1016/ j.jvolgeores.2006.09.003

Bennati L, Finizola A, Walker JA, Lopez DL, Higuera-Diaz IC, Schütze C, Barahona F, Cartagena R, Conde V, Funes R (2011) Fluid circulation in a complex volcano-tectonic setting, inferred from self-potential and soil CO2 flux surveys: the Santa María-Cerro Quemado-Zunil volcanoes and Xela caldera (Northwestern Guatemala). J Volcanol Geotherm Res 199(3-4):216-229. doi:10.1016/ j.jvolgeores.2010.11.008

Bluth GJ, Branan YK, Rose WI, Watson IM, Matias O (2002) Observations of Santiaguito's eruptive and passive emissions. Eos Trans. AGU, 83(47), Fall Meet. Suppl., Abstract V72C-03.

Bluth GJS, Rose WI (2004) Observations of eruptive activity at Santiaguito volcano, Guatemala. J Volcanol Geotherm Res 136(34):297-302. doi:10.1016/j.volgeores.2004.06.001

Boardman JW, Kruse FA, Green RO (1995) Mapping target signatures via partial unmixing of AVIRIS data. Summaries, Fifth JPL Airborne Earth Science Workshop, JPL Publication 95-1 1(23-26).

Boudon G, Villemant B, Komorowski JC, Idelfonse P, Semet MP (1998) The hydrothermal system at Soufriere Hills Volcano, Montserrat (West Indies): characterization and role in the on-going eruption. Geophys Res Lett 25(19):3693-3696. doi:10.1029/98GL00985

Calder ES, Luckett R, Sparks RSJ, Voight B (2002) Mechanisms of lava dome instability and generation of rockfalls and pyroclastic flows at Soufriere Hills Volcano, Montserrat. Geol Soc Mem 21:173-190

Capra L, Macias JL, Scott KM, Abrams M, Garduno-Monroy VH (2002) Debris avalanches and debris flows transformed from collapses in the Trans-Mexican volcanic belt, Mexico; behavior, and implications for hazard assessment. J Volcanol Geotherm Res 113(1-2):81-110

Clark RN, Swayze GA, Gallagher A, King TVV, Calvin WM (1993) The U. S. Geological Survey digital spectral library, version 1: 0.2 to $0.3 \mu \mathrm{m}$. U. S. Geol Surv Open-File Report 93-592:1340.

Clavero JE, Sparks RSJ, Pringle MS, Polanco E, Gardeweg MC (2004) Evolution and volcanic hazards of Taapaca Volcanic Complex, Central Andes of Northern Chile. J Geol Soc London 161(4):603618. doi:10.1144/0016-764902-065

Cole PD, Calder ES, Druitt TH, Hoblitt R, Robertson R, Sparks RSJ, Young SR (1998) Pyroclastic flows generated by gravitational instability of the 1996-97 lava dome of Soufriere Hills Volcano, Montserrat. Geophys Res Lett 25:3425-3428

Crowley JK, Zimbelman DR (1997) Mapping hydrothermally altered rocks on Mount Rainier, Washington, with Airborne Visible/Infrared Imaging Spectrometer (AVIRIS) data. Geology 25(6):559-562

Crowley JK, Hubbard BE, Mars JC (2003) Analysis of potential debris flow source areas on Mount Shasta, California, by using airborne and satellite remote sensing data. Remote Sens Environ 87(23):345-358. doi:10.1016/j.rse.2003.08.003

Elsworth D, Voight B, Thompson G, Young SR (2004) Thermalhydrologic mechanism for rainfall-triggered collapse of lava domes. Geology 32(11):969. doi:10.1130/g20730.1

Escobar Wolf R, Gomez OM, Rose WI (2010) Geologic map of the Santiaguito Dome Complex, Guatemala. Geological Society of America, Boulder, CO. doi:10.1130/2010.DMCH008.

Finn CA, Sisson TW, Deszcz-Pan M (2001) Aerogeophysical measurements of collapse-prone hydrothermally altered zones at Mount Rainier volcano. Nature 409:600-603

Finn CA, Deszcz-Pan M, Anderson ED, John DA (2007) Threedimensional geophysical mapping of rock alteration and water content at Mount Adams, Washington: implications for lahar hazards. J Geophys Res 112(B10):10.1029/2006jb004783

Folkman MA, Pearlman J, Liao LB, Jarecke PJ (2001) EO-1/Hyperion hyperspectral imager design, development, characterization, and calibration. In: William LS, Yoshifumi Y (eds) Proceedings of SPIE, the International Society for Optical Engineering. pp 40-51.

Fournier RO (1985) The behavior of silica in hydrothermal solutions. Rev Econ Geol 2:45-61

Fuji-ta K, Ogawa Y, Ichiki M, Yamaguchi S, Makino Y (1999) Audio frequency magneto-telluric survey of Norikura Volcano in central Japan. J Volcanol Geotherm Res 90(3-4):209-217

Gao B, Heidebrecht KB, \& Goetz AFH (1993) Derivation of scaled surface reflectances from AVIRIS data. Remote Sens Environ 44:165-178

Gao B, Kaufman YJ (1998) Algorithm Theoretical Basis Document (ATBD) for the MODIS Near-IR water vapor algorithm. Product ID: MOD05-Total precipitable water. ATBD-MOD-03, version 1.0, revised 13 November 1998. http://modis.gsfc.nasa.gov/data/ atbd/atbd_mod03.pdf

Giggenbach $\bar{W} F$ (1988) Geothermal solute equilibria. Derivation of $\mathrm{Na}-\mathrm{K}-\mathrm{Mg}-\mathrm{Ca}$ geoindicators. Geochim Cosmochim Ac 52:27492765

Graetsch JR (1994) Structural characteristics of opaline and microcrystalline silica minerals. In: Heaney PJ, Prewitt CT, Gibbs GV (eds) Silica: physical behavior, geochemistry and materials applications, Reviews in Mineralogy. pp 209-232.

Graetsch JR, Gies H, Topalovic I (1994) NMR, XRD and IR study of microcrystalline opals. Phys Chem Miner 21:166-175

Harris AJL, Rose WI, Flynn LP (2003) Temporal trends in lava dome extrusion at Santiaguito 1922-2000. B Volcanol 65(2-3):77-89. doi:10.1007/s00445-002-0243-0

Harris AJL, Flynn LP, Matias O, Rose WI, Cornejo J (2004) The evolution of an active silicic lava flow field: an ETM+ perspective. J Volcanol Geotherm Res 135(1-2):147-168. doi:10.1016/ j.jvolgeores.2003.12.011

Harsanyi JC, Chang C (1994) Hyperspectral image classification and dimensionality reduction: an orthogonal subspace projection approach. IEEE Transactions on Geoscience and Remote Sensing 32 (4):779-785

Hillier S, Lumsdon DG (2008) Distinguishing opaline silica from cristobalites: a practical procedure and perspective based on $\mathrm{NaOH}$ dissolution. Clay Miner 43(3):477-486. doi:10.1180/ claymin.2008.043.3.11

Hoefs J (2004) Stable isotope geochemistry. Springer, Berlin

Holland ASP, Watson IM, Phillips JC, Caricchi L, Dalton MP (2011) Degassing processes during lava dome growth; insights from 
Santiaguito lava dome, Guatemala. J Volcanol Geotherm Res 202 (1-2):153-166. doi:10.1016/j.jvolgeores.2011.02.004

Hubbard BE (2001) Volcanic Hazards Mapping Using Aircraft, Satellite, and Digital Topographic Data: Pico de Orizaba (Citlaltepetl), Mexico. Dissertation, SUNY University at Buffalo.

Hubbard BE, Crowley JK, Zimbelman DR (2003) Comparative alteration mineral mapping using visible to shortwave infrared $(0.4$ $2.4 \mu \mathrm{m})$ Hyperion, ALI, and ASTER imagery. IEEE Transactions on Geoscience and Remote Sensing 41(6):1401-1411

Hunt GR, Ashley RP (1979) Spectra of altered rocks in the visible and near-infrared. Econ Geol 74:1613-1629

ImSpec (2004) Atmospheric CORrection Now (ACORN). http:// www.imspec.com

ITT (2010) ENVI 4.7 Digital image analysis. In: ITT visual information solutions.

Japanese International Corporation Agency (JICA), Instituto Geográfico Nacional (IGN), Instituto Nacional de Sismología, Meteorología e Hidrología (INSIVUMEH), Secretaría de Planificación y Programación de la Presidencia (SEGEPLAN) (2003) Estudio del establecimento de los mapas básicos y mapas de amenaza para el sistema de información geográphica de la República de Guatemala. In: JICA, Guatemala City, Guatemala.

John DA, Sisson TW, Breit GN, Rye RO, Vallance JW (2008) Characteristics, extent and origin of hydrothermal alteration at Mount Rainier Volcano, Cascades Arc, USA: implications for debrisflow hazards and mineral deposits. J Volcanol Geotherm Res 175(3):289-314. doi:10.1016/j.jvolgeores.2008.04.004

Johnson JB, Harris AJL, Sahetapy-Engel STM, Escobar Wolf R, Rose WI (2004) Explosion dynamics of pyroclastic eruptions at Santiaguito Volcano. Geophys Res Lett 31(6):5. doi:10.1029/2003gl019079

Johnson JB, Lees JM, Gerst A, Sahagian D, Varley N (2008) Long-period earthquakes and co-eruptive dome inflation seen with particle image velocimetry. Nature 456(7220):377-381. doi:10.1038/nature07429

Jones JB, Sanders JB, Segnit ER (1964) Structure of opal. Nature 204:990-991

Jones JB, Segnit ER (1971) The nature of opal. I: Nomenclature and constituent phases. J Geol Soc Australia 18:57-68

Kerle N (2002) Volume estimation of the 1998 flank collapse at Casita volcano, Nicaragua: a comparison of photogrammetric and conventional techniques. Earth Surf Proc Land 27(7):759-772. doi:10.1002/esp.351

Komori S, Kagiyama T, Hoshizumi H, Takakura S, Mimura M (2010) Vertical mapping of hydrothermal fluids and alteration from bulk conductivity: simple interpretation on the USDP-1 site, Unzen Volcano, SW Japan. J Volcanol Geotherm Res 198(3-4):339_ 347. doi:10.1016/j.jvolgeores.2010.09.019

Komorowski JC, Hoblitt RP, Sheridan MF (1997) Silicification and bercciation microtextures of the Mt. St. Helens' 1980 cryptodome-country rock interface: implications for hydrothermal fluid processes, precursory seismicity, and eruptive style. In: Volcanic activity and the environment (abstracts), International Association of Volcanology and Geochemistry of the Earth's Interior, General Assembly, Puerto Vallarta, Mexico, Jan 19-25 1997: 76.

Komorowski J-C, Legendre Y, Christopher T, Bernstein L, Stewart R, Joseph E, Fournier N, Chardot L, Finizola A, Wadge G, Syers R, Williams C, Bass V (2010) Insights into processes and deposits of hazardous vulcanian explosions at Soufrière Hills Volcano during 2008 and 2009 (Montserrat, West Indies), Geophys Res Lett 37 L00E19. doi:10.1029/2010GL042558

Lesparre N, Gibert D, Marteau J, Komorowski J-C, Nicollin F, Coutant O (2012) Density muon radiography of La Soufriere of Guadeloupe volcano: comparison with geological, electrical resistivity and gravity data. Geophys J Int 190(2):1008-1019. doi:10.1111/ j.1365-246X.2012.05546.x
Lopez DL, Williams SN (1993) Catastrophic volcanic collapse: relation to hydrothermal processes. Science 260:1794-1796

Lopez F (2004) Monimiento de sedimentos en el cauce del Rio Samala: Informe Final. Coordinatdora Nacional Para La Reduccion De Desastres:37.

Lynne BY, Campbell KA, Moore J, Browne PRL (2008) Origin and evolution of the Steamboat Springs siliceous sinter deposit, Nevada, U.S.A. Sediment Geol 210(3):111.

Mars JC, Rowan LC (2010) Spectral assessment of new ASTER SWIR surface reflectance data products for spectroscopic mapping of rocks and minerals. Remote Sens Environ 114(9):2011-2025. doi:10.1016/j.rse.2010.04.008

Matthews AJ, Barclay J, Carn S, Thompson G, Alexander J, Herd R, Williams C (2002) Rainfall-induced volcanic activity on Montserrat. Geophys Res Lett 29 (Copyright 2003, IEE):22-21.

Matthews AJ, Barclay J, Johnstone JE (2009) The fast response of volcano-seismic activity to intense precipitation: triggering of primary volcanic activity by rainfall at Soufrière Hills Volcano, Montserrat. J Volcanol Geotherm Res 184(3-4):405-415. doi:10.1016/j.jvolgeores.2009.05.010

Moore DM, Reynolds RC (1997) X-ray diffraction: identification and analysis of clay minerals. Oxford University Press, Oxford

NASA (2004) ASTER: Advanced Spaceborne Thermal Emission and Reflection Radiometer. http://asterweb.jpl.nasa.gov/

NASA (2008) ASTER User Advisory-February 5, 2008. http://asterweb.jpl.nasa.gov/latest.asp

NASA (2011) MODIS Web. http://modis.gsfc.nasa.gov/

Nicollin F, Gibert D, Beauducel F, Boudon G, Komorowski J-C (2006) Electrical tomography of La Soufrière of Guadeloupe Volcano: Field experiments, 1D inversion and qualitative interpretation. Earth Planet Sc Lett 244(3-4):709-724. doi:10.1016/ j.eps1.2006.02.020

Opfergelt S, Delmelle P, Boivin P, Delvaux B (2006) The 1998 debris avalanche at Casita volcano, Nicaragua: investigation of the role of hydrothermal smectite in promoting slope instability. Geophys Res Lett 33(15):4. doi:10.1029/2006gl026661

Pirajno F (2009) Hydrothermal processes and mineral systems. Springer, Dordrecht

Reid ME, Sisson TW, Brien DL (2001) Volcano collapse promoted by hydrothermal alteration and edifice shape, Mount Rainier, Washington. Geology 29(9):779-782

Rose WI (1972a) Notes on the 1902 eruption of Santa María Volcano, Guatemala. B Volcanol 36(1):29-45

Rose WI (1972b) Santiaguito Volcanic Dome, Guatemala. Geol Soc Am Bull 83(5):1413-1433

Rose WI (1973a) Nuée Ardente from Santiaguito Volcano, April 1973. B Volcanol 37:365-371

Rose WI (1973b) Pattern and mechanism of volcanic activity at the Santiaguito Volcanic Dome, Guatemala. B Volcanol 37:73-94

Rose WI (1987a) Volcanic activity at Santiaguito Volcano, 1976-1984. Geol S Am S 212:17-27

Rose WI (1987b) Santa María, Guatemala; bimodal soda-rich calcalkalic stratovolcano. J Volcanol Geotherm Res 33(1-3):109-129

Rose WI Jr, Stoiber RE, Bonis SB (1970) Volcanic activity at Santiaguito volcano, Guatemala, June 1968-August 1969. B Volcanol 34(1):295-307

van Ruitenbeek FJA, Debba P, van der Meer FD, Cudahy T, van der Meijde M, Hale M (2006) Mapping white micas and their absorption wavelengths using hyperspectral band ratios. Remote Sens Environ 102:211-222

Sahetapy-Engel STM (2004) Surface temperature and spectral measurements at Santiaguito lava dome, Guatemala. Geophys Res Lett 31(19):10.1029/2004g1020683

Sahetapy-Engel ST, Harris AJL (2008) Thermal structure and heat loss at the summit crater of an active lava dome. B Volcanol 71(1):1528. doi:10.1007/s00445-008-0204-3 
Sapper K (1904) Die vulkanischen Ereignisse in Mittelamerik in Jahre 1902. Neues Jahrbuch fur Mineralogie, Geologie und Paleontologie:39-90.

Sapper K, Termer F (1930) Die Vulkanische Tätigkeit in Mittelamerika im 20 Jahrhundert I. Teil. Zeitschrift für Vulkanologie 9:156-203

Sato H, Fujii T, Nakada S (1992) Crumbling of dacite dome lava and generation of pyroclastic flows at Unzen volcano. Nature 360:664-666

Scott KM, Macias JL, Naranjo JA, Rodriguez S, McGeehin JP (2001) Catastrophic debris flows transformed from landslides in volcanic terrains: mobility, hazard assessment, and mitigation strategies. US Geol Surv Prof Paper 1630:1-59

Sheridan MF, Bonnard C, Carreno R, Siebe C, Strauch W, Navarro M, Cruz Calero JC, Trujillo NB (1999) Report on the October 30 1998 rockfall/debris avalanche and breakout flow of Casita volcano, Nicaragua, triggered by Hurricane Mitch. Landslide News $12: 2-4$

Simmons J, Elsworth D, Voight B (2004) Instability of exogenous lava lobes during intense rainfall. B Volcanol 66(8):725-734. doi:10.1007/s00445-004-0353-y

Sparks RSJ, Barclay J, Calder ES, Herd RA, Komorowski JC, Luckett R, Norton GE, Ritchie LJ, Voight B, Woods AW (2002) Generation of a debris avalanche and violent pyroclastic density current on 26 December (Boxing Day) 1997 at Soufriere Hills Volcano, Montserrat. Geol Soc Mem 21:409-434

Stoiber RE, Rose WI (1969) Recent volcanic and fumarolic activity at Santiaguito Volcano, Guatemala. B Volcanol 33 (2):475-502

Stoiber RE, Rose WI (1974) Fumarole incrustations at active Central American volcanoes. Geochim Cosmochim Ac 38 (4):495-516

Taylor HP (1979) Oxygen and hydrogen isotope relationships in hydrothermal mineral deposits. In: Barnes HL (ed) Geochemistry of hydrothermal ore deposits. Wiley-Interscience, New York, pp 236-277

Templeton S (1999) Hydrothermal systems at Volcan Santa María, Guatemala. In: Geology and Environmental Sciences. Northern Illinois University, p 166
Thompson AJB, Thompson JFH (1996) Atlas of alteration; a field and petrographic guide to hydrothermal alteration minerals. In: Dunne KPE (ed) Special Publication-Geological Association of Canada. Mineral Deposits Division. Geological Association of Canada. Mineral Deposits Division, St. John's, Newfoundland, Canada, p 119

Utada M (1980) Hydrothermal alteration related to igneous activity in Cretaceous and Neogene formations of Japan. Kozan Chishitsu= Mining. Geology 8:67-83

Vallance JW, Siebert L, Rose WI Jr, Giron JR, Banks NG (1995) Edifice collapse and related hazards in Guatemala. J Volcanol Geotherm Res 66(1-4):337-355

Velde B (1995) Origin and mineralogy of clays. Springer, Berlin, p 334 Venzke E, Wunderman RW, McClelland L, Simkin T, Luhr JF, Siebert L, Mayberry G, Sennert S (2002-2012) Global volcanism, 1968 to the present. In: Global Volcanism Program Digital Information Series, GVP-4. Smithsonian Institution, Washington, DC. http:// www.volcano.si.edu/reports/

Voight B, Komorowski JC, Norton GE, Belousov AB, Belousova M, Boudon G, Francis PW, Franz W, Heinrich P, Sparks RSJ, Young SR (2002) The 26 December (Boxing Day) 1997 sector collapse and debris avalanche at Soufriere Hills Volcano, Montserrat. Geol Soc Mem 21:363-407

Walker JA, Templeton S, Cameron BI (2006) The chemistry of spring waters and fumarolic gases encircling Santa María Volcano, Guatemala; insights into regional hydrothermal activity and implications for volcano monitoring. Geol Soc Am Spec Paper 412:59-83

Williams SN, Self S (1983) The October 1902 Plinian eruption of Santa María Volcano, Guatemala. J Volcanol Geotherm Res 16(1-2):33-56

Winterton J (1903) The volcanic eruptions in Guatemala. Sci Am 89(5):1

Wohletz KH, Heiken G (1992) Surface manifestations of geothermal systems. In: Volcanology and geothermal energy. University of California Press, Berkeley, pp 120-141

Zimbelman DR, Rye RO, Breit GN (2005) Origin of secondary sulfate minerals on active andesitic stratovolcanoes. Chem Geol 215:3760. doi:10.1016/j.chemgeo.2004.06.056 